Research Paper

\title{
Smac mimetic LCL161 supports neuroblastoma chemotherapy in a drug class-dependent manner and synergistically interacts with ALK inhibitor TAE684 in cells with ALK mutation F1174L
}

\author{
Safiullah Najem ${ }^{1}$, Doerte Langemann ${ }^{1}$, Birgit Appl ${ }^{1}$, Magdalena Trochimiuk ${ }^{1}$, \\ Patrick Hundsdoerfer ${ }^{2}$, Konrad Reinshagen ${ }^{1}$ and Georg Eschenburg ${ }^{1}$ \\ ${ }^{1}$ Department of Pediatric Surgery, University Medical Center Hamburg-Eppendorf, Hamburg, Germany \\ 2 Department of Pediatric Oncology/Hematology, Charité - Universitätsmedizin Berlin, Berlin, Germany \\ Correspondence to: Georg Eschenburg, email: g.eschenburg@uke.de \\ Keywords: neuroblastoma, LCL161, Smac mimetics, chemotherapy, anaplastic lymphoma kinase \\ Received: January 06, $2016 \quad$ Accepted: August 27, $2016 \quad$ Published: September 15, 2016
}

\section{ABSTRACT}

Neuroblastoma is the most common extracranial solid tumor during infancy and childhood.

Outcome of high-risk and late-stage disease remains poor despite intensive treatment regimens.

Suppressing inhibitor of apoptosis proteins (IAPs) using Smac mimetics (SM) significantly sensitizes neuroblastoma (NB) cells for chemotherapy, however strongly dependent on the cytotoxic drug combined with SM.

Therefore, a systematic analysis of the impact of SM in combination with different classes of chemotherapeutics was of crucial importance. Treatment of NB cell lines with SM LCL161 and vinca alkaloids revealed a strong synergistic inhibition of proliferation and significant induction of apoptosis in virtually all established and de novo NB cell lines $(n=8)$.

In contrast, combination of anthracyclines or topoisomerase inhibitors with LCL161 showed a synergism for single drugs and/or cell lines only.

Furthermore, we could show that insensibility to LCL161-mediated sensitization for chemotherapeutics is associated with aberrant activation of anaplastic lymphoma kinase (ALK) by common mutation F1174L. Inhibition of ALK using TAE684 is able to overcome this resistance in a synergistic fashion, a finding that could be highly relevant for improvement of neuroblastoma therapy.

\section{INTRODUCTION}

Neuroblastoma is a malignant disease of the sympathetic nervous system and the most prevalent solid extracranial tumor during infancy and childhood. Prognosis for non-high risk disease is good with 5-year survival $>90 \%$, at the same time more than $50 \%$ of patients suffer from metastatic disease at time of diagnosis $[1,2]$. Outcome for these patients is still poor in spite of significant therapy improvements in the last years including differentiation therapy or immunotherapy [3]. Development of novel treatment options is therefore absolutely essential and a key objective in pediatric oncology $[4,5]$.

Apoptosis is a form of programmed cell death that is necessary to eradicate impaired cells and to enable realization of developmental programs. Deregulated apoptotic machinery is one of the hallmarks of cancer contributing to development and expansion of diverse malignancies [6].

The family of inhibitor of apoptosis proteins (IAP) are essential regulators of apoptosis. X-linked IAP (XIAP), the most prominent and best-analyzed IAP, is increased in different cancers including neuroblastoma contributing to chemotherapy resistance and unfavorable outcome [710]. Caspase activation essential for apoptosis induction is inhibited by direct binding of XIAP to caspases-3/-7/-9 [11]. Second mitochondria-derived activator of caspase (Smac) is released from the mitochondria in response to different apoptotic stimuli. IAPs are antagonized by interaction of their BIR2 and BIR3 domains with the AVPI tetrapeptide motif of Smac [12]. Using this motif as a blue print for the development of small molecule IAP antagonists (Smac mimetics) has shown to be a promising 
strategy for treatment of malignancies associated with XIAP overexpression.

Smac mimetics (SM) were able to induce apoptosis and to significantly increase efficacy of classic treatment in several experimental cancer models [10, 13]. In neuroblastoma cell lines we could demonstrate a sensitization against cytotoxic drugs currently used in neuroblastoma therapy in vitro and in a syngeneic mouse model using SM LBW242 and LCL161 [7]. LBW242 and LCL161 are structural analogs with similar molecular weight; the latter was optimized for potency and pharmacokinetics [14]. Several clinical trials are currently conducted to evaluate the capacity of Smac mimetics for the treatment of resistant malignant diseases [15].

Sensitization of neuroblastoma cells for chemotherapy using SM was highly synergistic for vincristine, in part synergistic for doxorubicin and antagonistic for etoposide [7].

If the synergistic interaction of SM is drugdependent or related to the molecular background of the neuroblastoma cells is still unanswered.

Therefore, a systematic effect analysis of different classes of antineoplastic drugs in combination with SM was the logical next step to shed light on this relevant issue. In the current study, we could show that in all except one of the tested neuroblastoma cell lines vinca alkaloids (vinblastine, vindesine and vincristine) with SM LCL161 displayed a strong synergistic effect on proliferation and a significant apoptosis induction in line with the results obtained before. Using anthracyclines (daunorubicin, doxorubicin and idarubicin) or topoisomerase inhibitors (etoposide, topotecan and $\mathrm{SN}-38$ ) in contrast a synergism with LCL161 was detectable for single drugs and/or cell lines only.

\section{RESULTS}

Smac mimetic LBW242 displayed a synergistic gain of chemotherapy on neuroblastoma cell lines in a drug-dependent manner [7]. Different classes of chemotherapeutics used in neuroblastoma therapy were thus selected for a systematic analysis of their combination effect with Smac mimetics (SM). LCL161, a structural analog of LBW242, was used for this survey because it is well tolerated in humans and mice $[16,17]$, and showed synergistic cooperation with vincristine in neuroblastoma in vivo as well [7]. Furthermore, LCL161 is currently evaluated in several clinical trials (www.clinicaltrials.gov).

\section{Protein expression of XIAP and cIAP-1 and influence on cellular proliferation and apoptosis following LCL161-treatment in neuroblastoma}

Apoptosis induction by SM is thought to be directly correlated to their binding and inactivation of XIAP and degradation of cIAP-1 respectively [10, 18-20]. Therefore we determined the abundance of cIAP-1 and XIAP protein in neuroblastoma cell lines $(n=6)$ using Western blot analysis (Figure 1A). Slight differences in expression levels for cIAP-1 and two specific XIAP protein bands were observed. We have demonstrated cIAP-1 degradation and constant XIAP expression in neuroblastoma cells following treatment with SM LBW242 [7]. Treatment of cells using LCL161 for 30 min showed a similar picture (Figure 1B).

Then we evaluated proliferation and apoptosis induction of human neuroblastoma cell lines $(n=6)$ in the presence of SM LCL161 monotherapy. Significant inhibition of proliferation was detected using high micromolar concentrations with $\mathrm{IC}_{50}$ of 49.4-77.9 $\mu \mathrm{M}$ (Figure 1C and Table 1A). For all following experiments concerning combinations of LCL161 with chemotherapeutic drugs a concentration of $10 \mu \mathrm{M}$ LCL161 was used. With this concentration only marginal effects on proliferation and apoptosis induction of the tested neuroblastoma cell lines were observed (Figure 1D).

\section{Effects of combination of LCL161 with vinca alkaloids on cellular proliferation}

Treatment of neuroblastoma cell lines with vinca alkaloids (vinblastine, vincristine and vindesine) showed a concentration-dependent inhibition of proliferation (Figure 2 and Table 1A). Vinblastine was the most potent vinca drug with $\mathrm{IC}_{50}$ of 3.7-16.4 $\mathrm{nM}$ followed by vindesine $\left(\mathrm{IC}_{50} 9.1-121 \mathrm{nM}\right)$ and vincristine $\left(\mathrm{IC}_{50} 24.5-117 \mathrm{nM}\right)$. Combined treatment of LCL161 with each of the vinca alkaloids enhanced the antiproliferative potential of the drugs in a synergistic manner in all cell lines except SKN-BE(2)-M17 (Figure 2 and Tables 1A+1B). In this cell line only vindesine and LCL161 interacted synergistically.

\section{Antiproliferative effects of LCL161 co-treatment with anthracyclines}

Inhibition of cellular proliferation with anthracyclines disclosed a relative insensibility in comparison to treatment with vinca alkaloids (Figure 3 and Table 1A). Idarubicin induced the strongest decrease of cellular growth with $\mathrm{IC}_{50}$ of $42-223 \mathrm{nM}$. The $\mathrm{IC}_{50}$ of the other two anthracyclines were $0.35-1.58 \mu \mathrm{M}$ for daunorubicin and $0.12-2.58 \mu \mathrm{M}$ for doxorubicin. Addition of LCL161 enhanced the negative effect on proliferation of daunorubicin and doxorubicin in all cell lines, except Kelly, synergistically (Figures 3A+3B and Tables 1A+1B). Co-treatment of LCL161 with idarubicin showed a synergism only in the cell lines NB1691luc and SK-N-AS (Figure $3 \mathrm{C}$ and Tables $1 \mathrm{~A}+1 \mathrm{~B}$ ). 


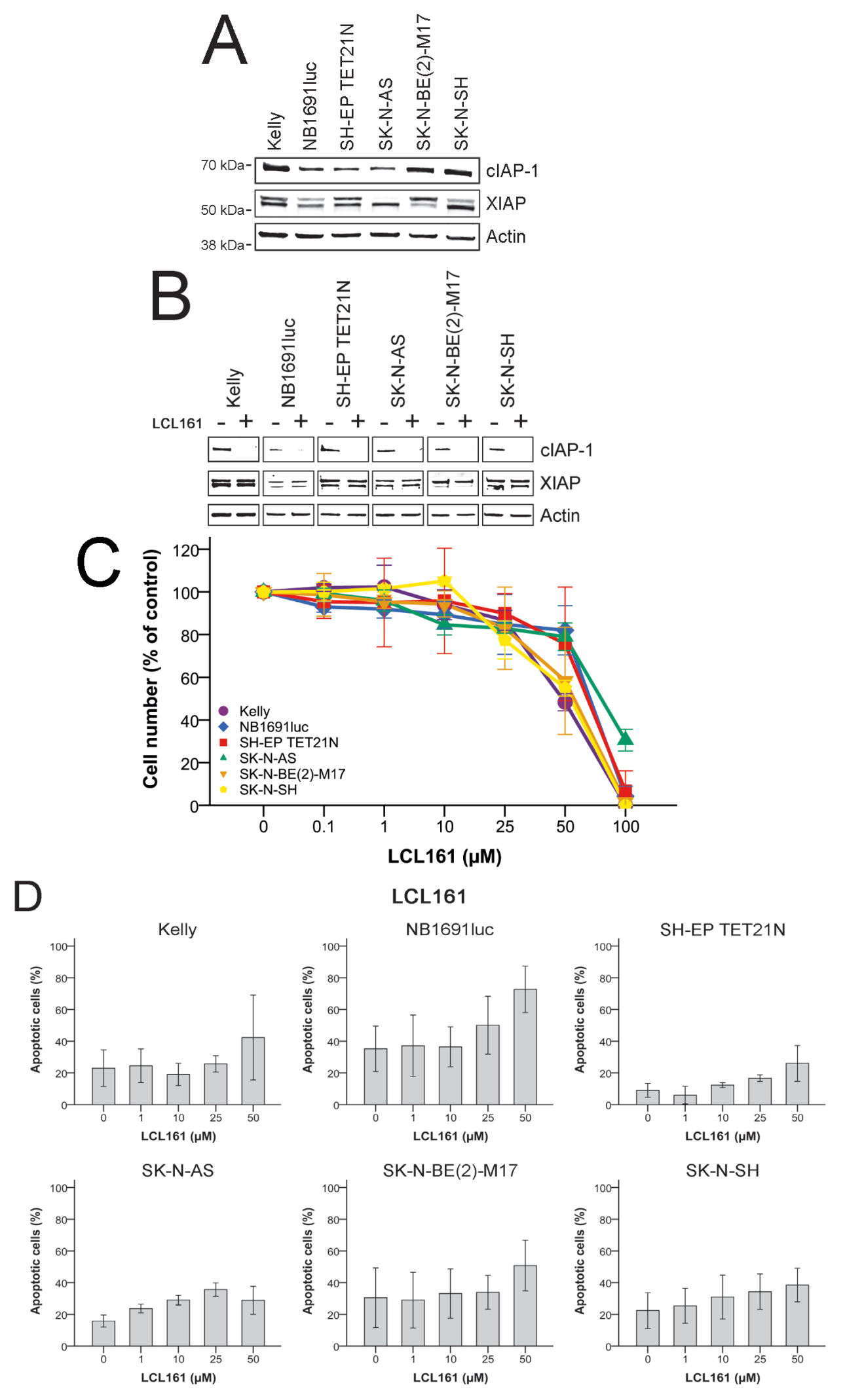

Figure 1: Effect of LCL161 on expression of cIAP-1 and XIAP, cell proliferation and induction of apoptosis in neuroblastoma cell lines. Expression of cIAP-1, XIAP and actin was detected by Western Blot analysis in untreated neuroblastoma cell lines A. and cells treated 30 min with $10 \mu \mathrm{M} \mathrm{LCL161} \mathrm{B..} \mathrm{Proliferation} \mathrm{of} \mathrm{cells} \mathrm{treated} \mathrm{with} \mathrm{the} \mathrm{indicated} \mathrm{concentrations} \mathrm{of} \mathrm{LCL161} \mathrm{was}$ determined after $48 \mathrm{~h}$ C.. Proliferation of untreated cells was defined as $100 \%$. The proportion of apoptotic cells was determined by flow cytometry (Annexin V and PI staining) $48 \mathrm{~h}$ after LCL161 treatment D.. Values represent the mean \pm SD of three independent experiments. 
Table 1: Established and de novo neuroblastoma cell lines are sensitized by LCL161 for chemotherapy-induced inhibition of cell proliferation.

\section{Table 1A}

\begin{tabular}{|c|c|c|c|c|c|c|c|c|c|c|c|c|c|c|c|c|c|c|c|}
\hline \multirow[b]{2}{*}{ 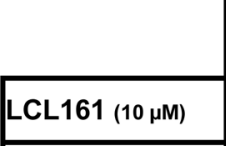 } & \multicolumn{2}{|c|}{$\begin{array}{c}\text { VBL } \\
\mathrm{IC}_{50}(\mathrm{nM})\end{array}$} & \multicolumn{2}{|c|}{$\begin{array}{c}\text { VCR } \\
\text { IC }_{50}(\mathrm{nM})\end{array}$} & \multicolumn{2}{|c|}{$\begin{array}{c}\text { VDS } \\
\mathrm{IC}_{50}(\mathrm{nM})\end{array}$} & \multicolumn{2}{|c|}{$\begin{array}{c}\text { DAU } \\
\mathrm{IC}_{50}(\mu \mathrm{M})\end{array}$} & \multicolumn{2}{|c|}{$\begin{array}{c}\mathrm{DOX} \\
\mathrm{IC}_{50}(\mu \mathrm{M})\end{array}$} & \multicolumn{2}{|c|}{$\begin{array}{c}\text { IDA } \\
\text { IC } \\
\text { I0 (nM) }\end{array}$} & \multicolumn{2}{|c|}{$\begin{array}{c}\text { ETO } \\
\mathrm{IC}_{50}(\mu \mathrm{M})\end{array}$} & \multicolumn{2}{|c|}{$\begin{array}{l}\mathrm{SN}-38 \\
\mathrm{IC}_{50}(\mu \mathrm{M}) \\
\end{array}$} & \multicolumn{2}{|c|}{$\begin{array}{c}\text { TOPO } \\
\mathrm{IC}_{50}(\mu \mathrm{M})\end{array}$} & \multirow[b]{2}{*}{$\begin{array}{l}\text { LCL161 } \\
\text { IC }_{50}(\mu \mathrm{M}) \\
\end{array}$} \\
\hline & - & + & - & + & - & + & - & + & - & + & - & + & - & + & - & + & - & + & \\
\hline Kelly & 16 & 5.4 & 79 & 20 & 48 & 20 & .38 & .29 & .84 & .65 & 74 & 72 & 4.6 & 3.1 & .04 & .03 & .08 & .08 & 49 \\
\hline NB1691luc & 3.7 & 1.4 & 25 & 1.5 & 9.1 & 0.9 & 1.6 & .80 & 2.6 & .24 & 158 & 85 & 23 & 22 & .35 & .22 & 1.2 & 1.1 & 69 \\
\hline SH-EP TET21N & 13 & 4.1 & 37 & 18 & 26 & 13 & .61 & .36 & .6 & .41 & 172 & 171 & 24 & 23 & 1.6 & 1.3 & 1 & 0.8 & 73 \\
\hline SK-N-AS & 5.6 & 4.2 & 42 & 20 & 19 & 6.3 & .37 & .20 & 1.4 & .35 & 223 & 110 & 27 & 20 & .53 & .38 & .78 & .22 & 78 \\
\hline SK-N-BE(2)-M17 & 7.9 & 6.2 & 117 & 110 & 121 & 34 & .44 & .27 & .24 & .11 & 56 & 45 & 29 & 24 & .05 & .03 & .57 & .48 & 59 \\
\hline SK-N-SH & 5.6 & 3.9 & 79 & 7.1 & 58 & 12 & .35 & .23 & .12 & .05 & 42 & 34 & .54 & .44 & .01 & .01 & .08 & .07 & 56 \\
\hline HGW-1 & 6.4 & 2.2 & 22 & 4.7 & 16 & 4.2 & .09 & .07 & .41 & .15 & 48 & 47 & 4.9 & 1.8 & .04 & .03 & .73 & .27 & 34 \\
\hline HGW-3 & 12 & 2.1 & 33 & 4.7 & 39 & 4.5 & .06 & .04 & .04 & .02 & 29 & 26 & 7.5 & 1.8 & .05 & .04 & .02 & .02 & 71 \\
\hline
\end{tabular}

\section{Table 1B}

\begin{tabular}{|c|c|c|c|c|c|c|c|c|c|}
\hline & \begin{tabular}{|c|} 
VBL + \\
LCL161 \\
CI(II 50$)$ \\
\end{tabular} & $\begin{array}{c}\text { VCR + } \\
\text { LCL161 } \\
\left.\text { Cl(IC } \text { IC }_{50}\right) \\
\end{array}$ & $\begin{array}{c}\text { VDS + } \\
\text { LCL161 } \\
\text { Cl(II } 50) \\
\end{array}$ & $\begin{array}{c}\text { DAU + } \\
\text { LCL161 } \\
\left.\text { Cl(IC } \text { I }_{50}\right) \\
\end{array}$ & \begin{tabular}{|c|} 
DOX + \\
LCL161 \\
Cl(II $\left._{50}\right)$ \\
\end{tabular} & $\begin{array}{c}\text { IDA + } \\
\text { LCL161 } \\
\left.\text { Cl(II }{ }_{50}\right) \\
\end{array}$ & \begin{tabular}{|c|} 
ETO + \\
LCL161 \\
Cl(II II $\left._{50}\right)$ \\
\end{tabular} & $\begin{array}{c}\text { SN-38+ } \\
\text { LCL161 } \\
\mathrm{Cl}\left(\mathrm{IC}_{50}\right) \\
\end{array}$ & \begin{tabular}{|c} 
TOPO + \\
LCL161 \\
Cl(IC $\left.1 C_{50}\right)$ \\
\end{tabular} \\
\hline Kelly & 0.53 & 0.45 & 0.62 & 0.96 & 0.98 & 1.18 & 0.88 & 0.93 & 1.20 \\
\hline NB1691luc & 0.53 & 0.21 & 0.24 & 0.65 & 0.24 & 0.68 & 1.11 & 0.79 & 1.08 \\
\hline SH-EP TET21N & 0.46 & 0.64 & 0.65 & 0.72 & 0.82 & 1.13 & 1.10 & 0.96 & 0.90 \\
\hline SK-N-AS & 0.88 & 0.60 & 0.46 & 0.67 & 0.52 & 0.62 & 0.89 & 0.85 & 0.41 \\
\hline SK-N-BE(2)-M17 & 0.95 & 1.11 & 0.45 & 0.77 & 0.63 & 0.97 & 0.98 & 0.77 & 1.01 \\
\hline SK-N-SH & 0.88 & 0.27 & 0.39 & 0.83 & 0.60 & 0.99 & 0.99 & 0.95 & 1.02 \\
\hline HGW-1 & 0.64 & 0.50 & 0.56 & 1.06 & 0.66 & 1.27 & 0.66 & 1.12 & 0.66 \\
\hline HGW-3 & 0.32 & 0.28 & 0.26 & 0.77 & 0.73 & 1.05 & 0.38 & 0.99 & 1.14 \\
\hline
\end{tabular}

$\mathrm{IC}_{50}$ values for dose-effect curves were determined (A). Reduction of $\mathrm{IC}_{50}$ by LCL161 is illustrated by red shading $(=<10 \%$,

$$
=\square 10-29 \%, \square=30-49 \%, \square=50-69 \%, \square=\geq 70 \% \text { ). }
$$

$\mathrm{IC}_{50}$ were taken as a basis for the calculation of combination indices (CI) using the Chou-Talay method (B).

Range of CI values and correlating intensity of synergism is illustrated by red shading ( $\square=$ nearly additive (CI $>0.9-1.1)$ or antagonistic $(\mathrm{CI}>1.1),=\square$ slight synergism $(\mathrm{CI}=0.9-0.86),=\square$ moderate synergism $(\mathrm{CI}=0.85-0.71),=\square$ synergism $(\mathrm{CI}=0.7-0.31)$, = strong $\square$ synergism $(\mathrm{CI} \leq 0.3))$.

VBL, vinblastine; VCR, vincristine; VDS, vindesine; DAU, daunorubicin; DOX, doxorubicin; IDA, idarubicin; ETO, etoposide; TOPO, topotecan. 
A
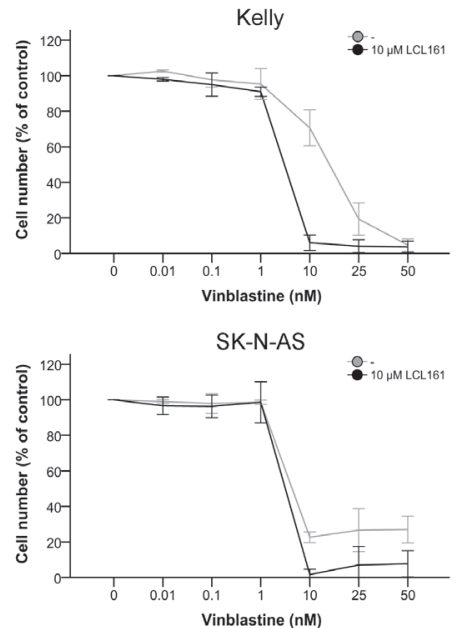

B
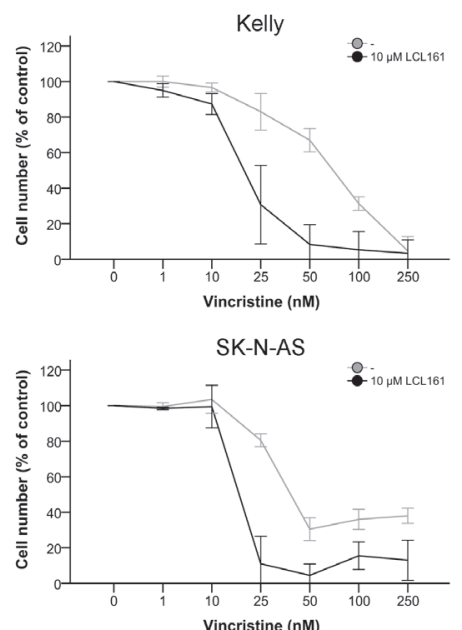

C
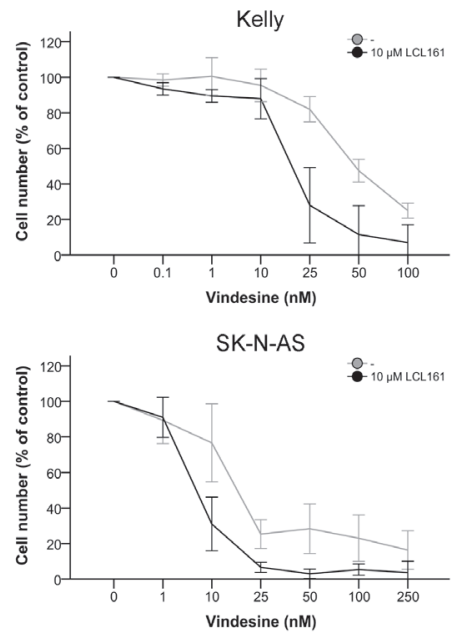
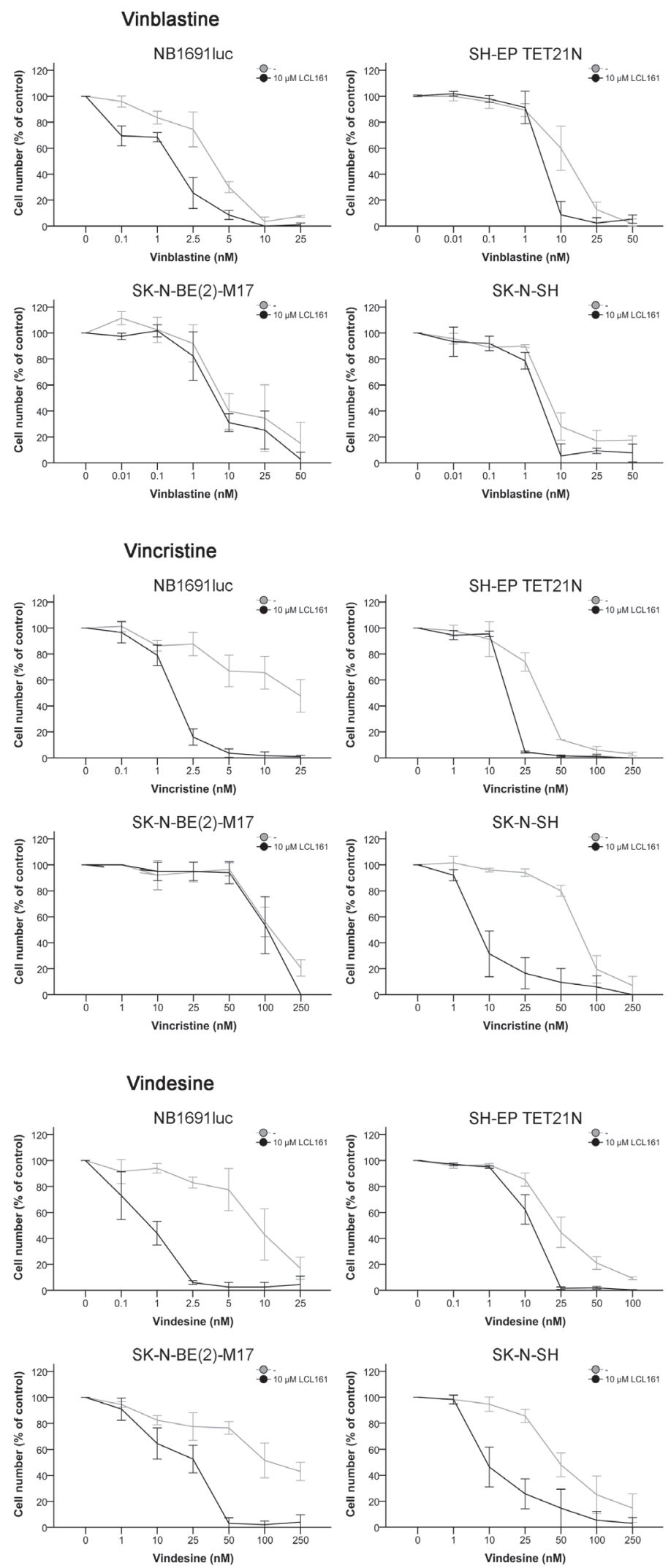

Figure 2: Inhibition of cell proliferation in neuroblastoma cell lines by vinca alkaloids and their combination with LCL161. Cells were treated with the indicated concentrations of vinblastine A., vincristine B., vindesine C. or LCL161 A.-C. and proliferation was determined after $48 \mathrm{~h}$. Proliferation of untreated cells was defined as $100 \%$. Values represent the mean \pm SD of three independent experiments. 
A
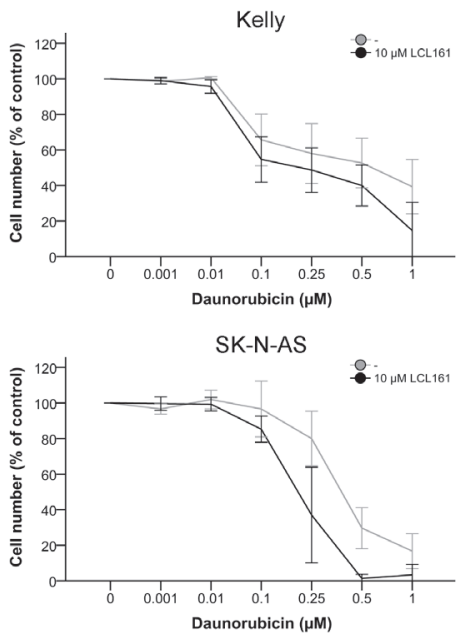

B
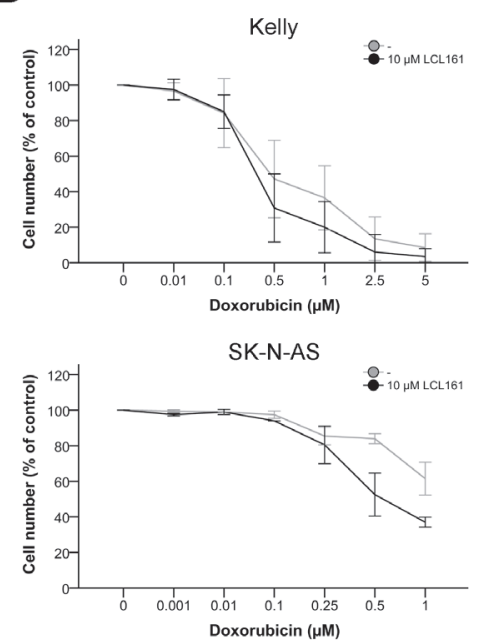

C
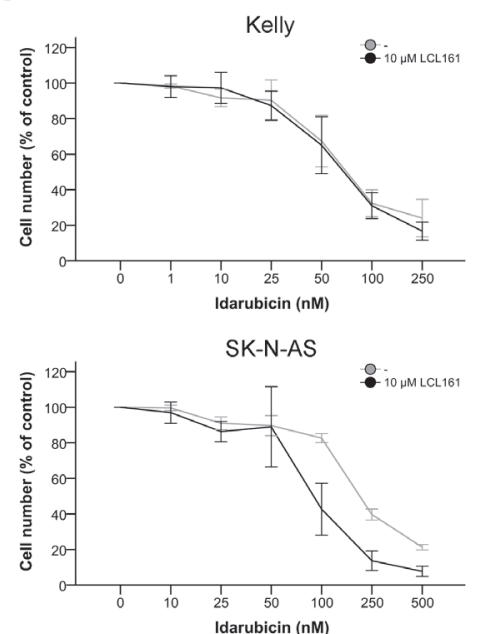

Daunorubicin
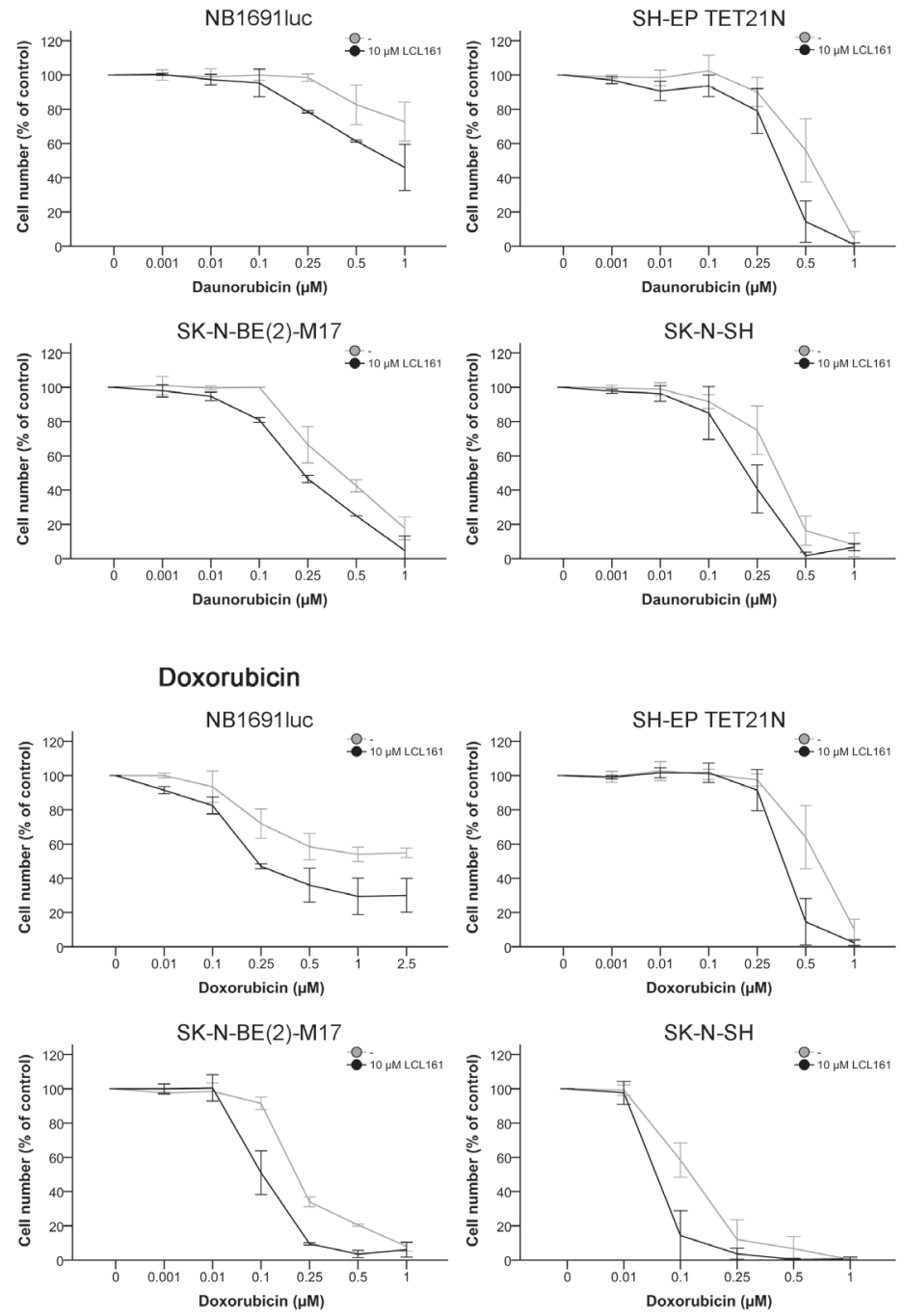

Idarubicin
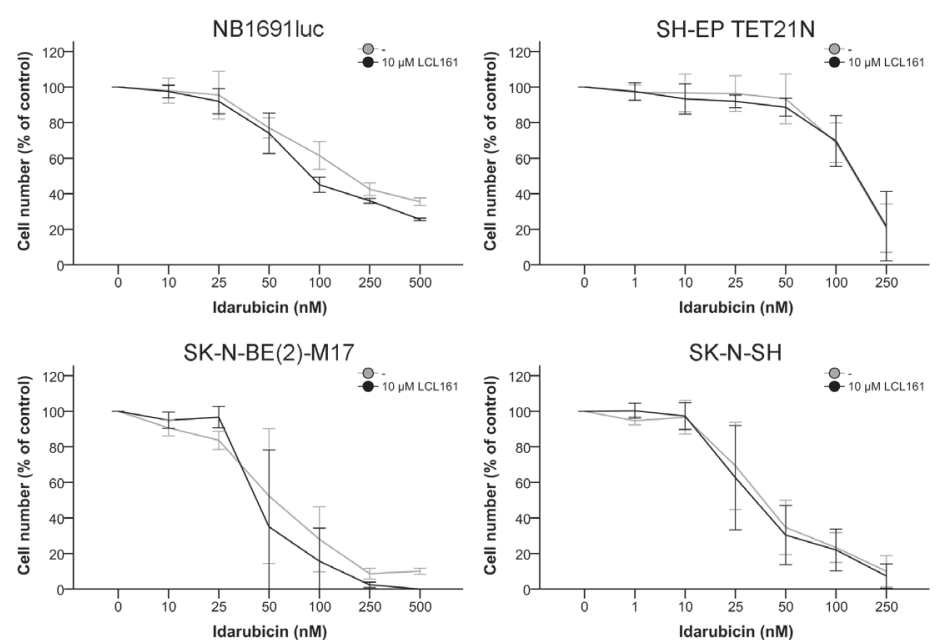

Figure 3: Inhibition of cell proliferation in neuroblastoma cell lines by anthracyclines and their combination with LCL161. Cells were treated with the indicated concentrations of daunorubicin A., doxorubicin B., idarubicin C. or LCL161 A.-C. and proliferation was determined after $48 \mathrm{~h}$. Proliferation of untreated cells was defined as $100 \%$. Values represent the mean \pm SD of three independent experiments. 
A
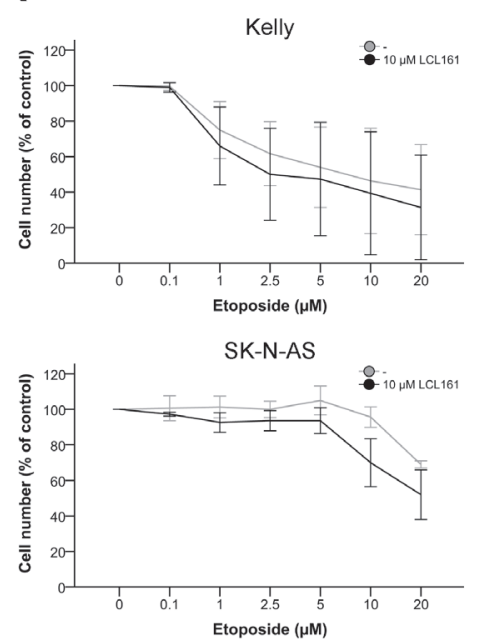

B
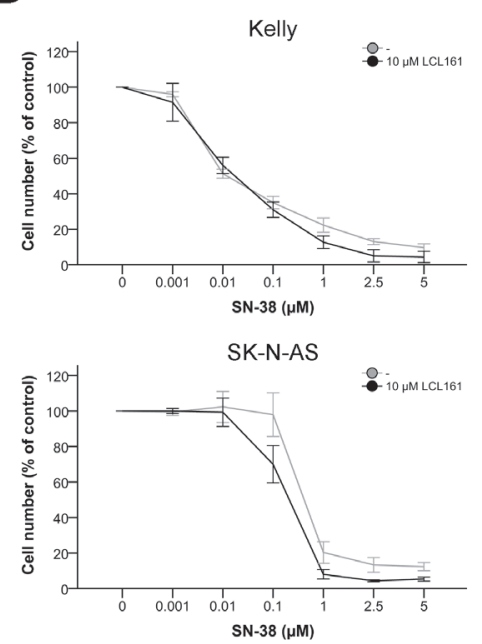

C
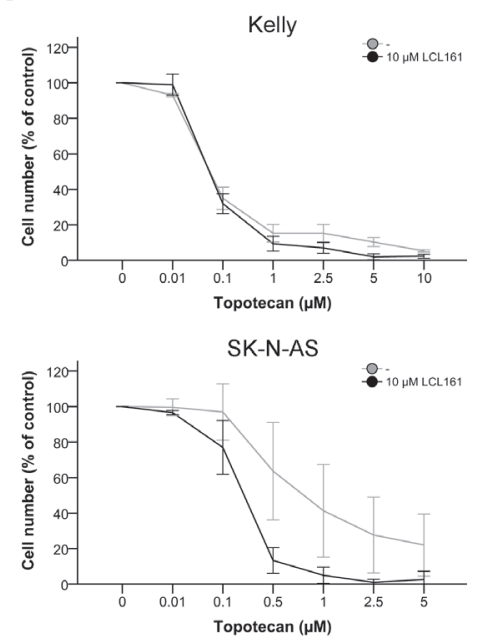

Etoposide
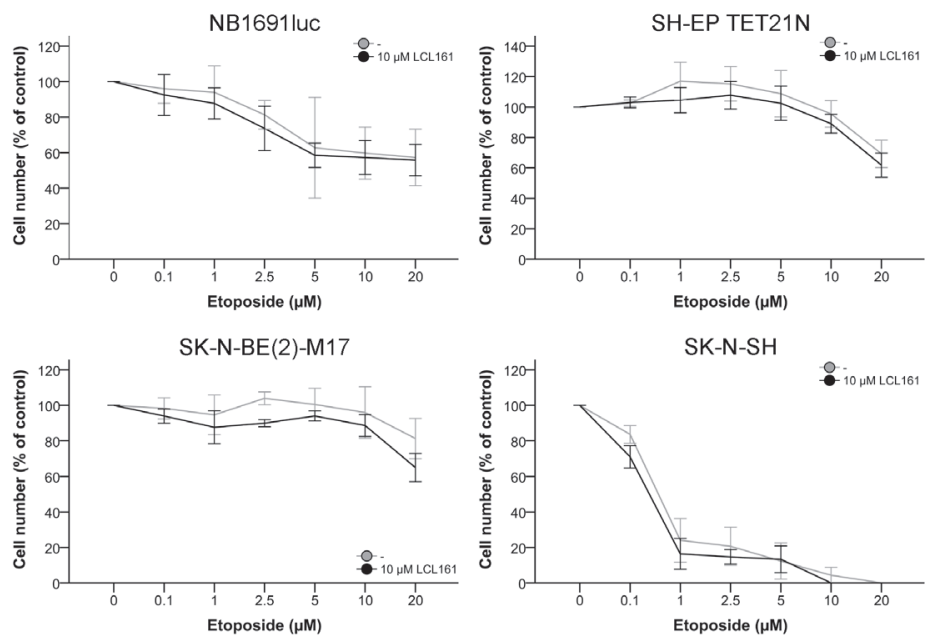

SN-38
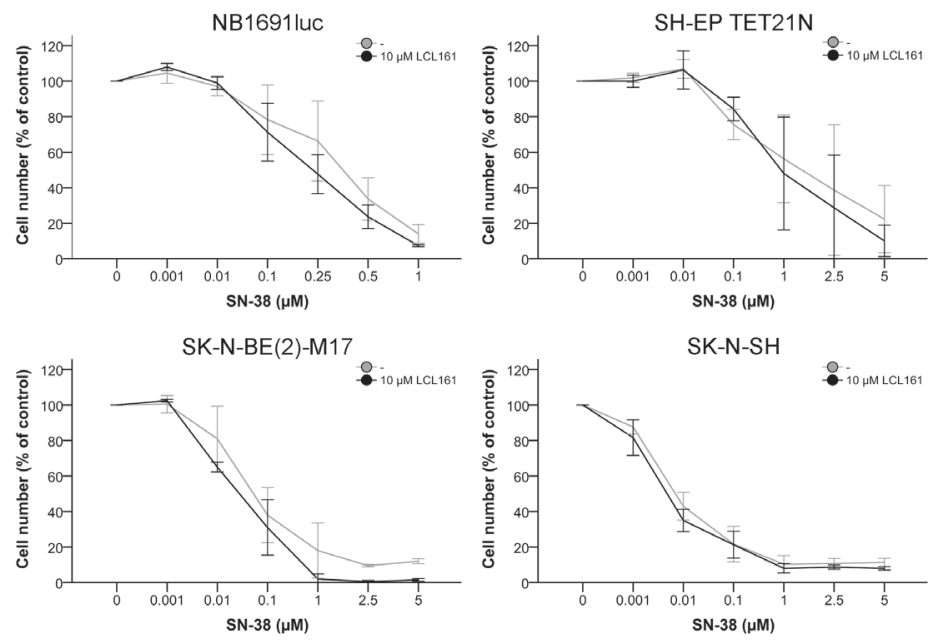

Topotecan
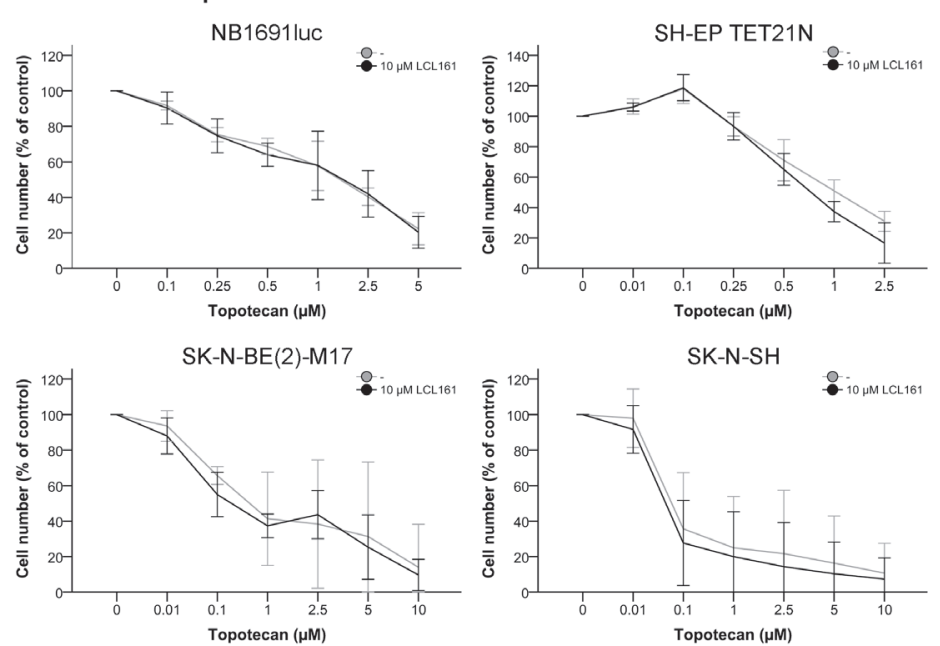

Figure 4: Inhibition of cell proliferation in neuroblastoma cell lines by topoisomerase inhibitors and their combination with LCL161. Cells were treated with the indicated concentrations of etoposide A., SN-38 B., topotecan C. or LCL161 A.-C. and proliferation was determined after $48 \mathrm{~h}$. Proliferation of untreated cells was defined as $100 \%$. Values represent the mean \pm SD of three independent experiments. 
Table 2. Molecular features of neuroblastoma cell lines and de novo cell lines.

\begin{tabular}{|c|c|c|c|c|}
\hline NB cell line & MYCN & Chromosome 1 & ALK & p53 \\
\hline Kelly & $>100 x$ amplified[58] & $\operatorname{del}(1 p)$ & F1174L[48] & wt[59] \\
\hline NB1691luc & amplified $^{\mathrm{a}}$ & $w t^{\mathrm{a}}$ & $\mathrm{wt}[60]$ & $\mathrm{wt}[61]$ \\
\hline SH-EP TET21N & wt (conditional MYCN expression) $[55,62]$ & $+1 \mathrm{q}[62]$ & F1174L[48] & $\mathrm{wt}[61]$ \\
\hline SK-N-AS & wt [63] & $\operatorname{del}(1 p)[63]$ & wt[48] & mutated[64] \\
\hline SK-N-BE(2)-M17 & amplified[62] & $\operatorname{del}(1 p), t(1 p)[62]$ & wt[48] & mutated $[65,66]$ \\
\hline SK-N-SH & wt[62] & $+1 \mathrm{q}[62]$ & F1174L[48] & wt[67] \\
\hline HGW-1 & amplified[54] & $+1 \mathrm{q}[54]$ & unknown & unknown \\
\hline HGW-3 & amplified[54] & $\operatorname{del}(1 p)[54]$ & unknown & unknown \\
\hline
\end{tabular}

F1174: The F1174L mutation results in an amino acid substitution at position 1174 in ALK from a phenylalanine (F) to a leucine (L). a; Peter Houghton, personal communication

\section{LCL161 and topoisomerase inhibitor-induced inhibition of proliferation}

Five of the six tested cell lines with exception of SK-N-SH $\left(\mathrm{IC}_{50} 0.54 \mu \mathrm{M}\right)$ were unresponsive against etoposide with $\mathrm{IC}_{50}$ of 4.6-29.1 $\mu \mathrm{M}$ (Figure 4A and Table 1A).

In contrast proliferation of neuroblastoma cell lines treated with topoisomerase inhibitors $\mathrm{SN}-38\left(\mathrm{IC}_{50} 0.013-\right.$ $1.56 \mu \mathrm{M})$ and topotecan $\left(\mathrm{IC}_{50} 0.08-1.17 \mu \mathrm{M}\right)$ was inhibited to a similar degree (Figures $4 \mathrm{~B}+4 \mathrm{C}$ and Table $1 \mathrm{~A}$ ).

Application of LCL161 had marginal effects on the antiproliferative impact of topoisomerase inhibitors. Only in the cell line SK-N-AS addition of LCL161 resulted in a synergistic topotecan-induced inhibition of proliferation (Figure 4C and Tables 1A+1B). In all other cell lines LCL161 was not able to substantially increase the inhibition of proliferation of either etoposide, SN-38 or topotecan leading to additive/antagonistic effects or only slight to moderate synergism (Figure 4 and Tables $1 \mathrm{~A}+1 \mathrm{~B})$.

\section{Antiproliferative effect of LCL161 and chemotherapy in de novo NB cell lines}

In order to validate that the preceding observations were not restricted to long-term cultivated cell lines proliferation assays were expanded to low passage de novo neuroblastoma cell lines HGW-1 and HGW-3. Both were highly sensitive for chemotherapy in general and combination with LCL161 induced effects comparable to that of the established neuroblastoma cell lines (Figures $\mathrm{S} 1$ and S2 and Tables 1A+1B). Again, the inhibition of proliferation induced by all vinca alkaloids could be increased by LCL161 leading to (strong) synergism (Figure S2A and Tables 1A+1B). Combinations of LCL161 with anthracyclines or topoisomerase inhibitors elicited a synergism only for single drugs or cells similar to the results obtained before (Figures $\mathrm{S} 2 \mathrm{~B}+\mathrm{S} 2 \mathrm{C}$ and Tables 1A+1B).

\section{LCL161-mediated sensitization for vinca alkaloid- induced apoptosis}

With the intention to shed light on the sensitization for vinca alkaloid-induced inhibition of proliferation by LCL161, cells were analyzed for apoptosis induction using flow cytometry. According to the proliferation experiments combined treatment of LCL161 with vinca alkaloids resulted in a considerable increase of apoptosis in all cell lines except SK-N-BE(2)-M17 (Figures 5A-5C). In four respectively five of the six cell lines a significant sensitization for vinblastine- and vincristine-induced apoptosis by LCL161 was observed (Figures $5 \mathrm{~A}+5 \mathrm{~B}$ ). In line with the proliferation data all cell lines were susceptible for the combined treatment of vindesine and LCL161 leading to a significant increase of apoptotic cells (Figure 5C).

\section{Apoptosis induction by anthracyclines and LCL161}

Neuroblastoma cell lines were treated with LCL161 in combination with anthracyclines to evaluate the effects on apoptosis induction (Figures 6A-6C). In all cell lines beside Kelly a significant increase in apoptosis was observed by application of LCL161 to daunorubicin correlating with the synergisms observed in the proliferation assays (Figure 6A). A similar pattern was detected for doxorubicin (Figure 6B).

However, unexpectedly no obvious differences in apoptosis were found for doxorubicin and its combination with LCL161 in SK-N-BE(2)-M17 that displayed a synergistic $\left(\mathrm{CI}\left(\mathrm{IC}_{50}\right)\right.$ 0.63) inhibition of proliferation in the 
A
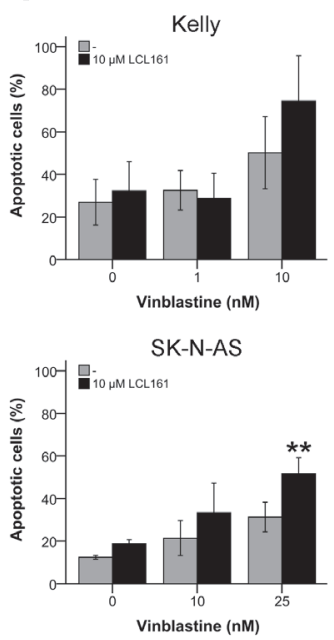

B
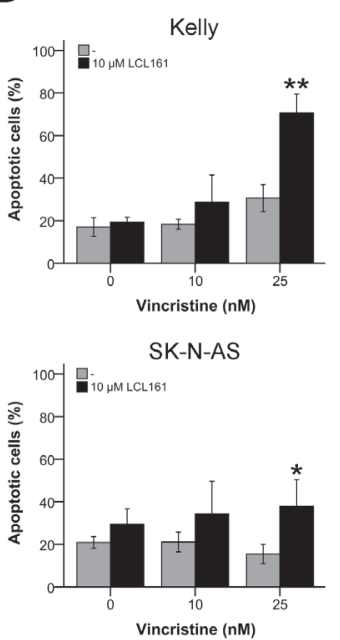

C
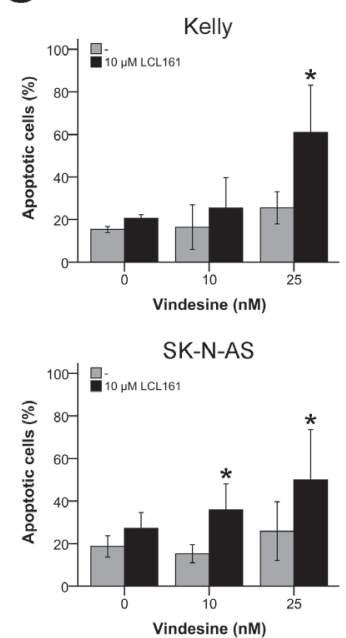

Vinblastine
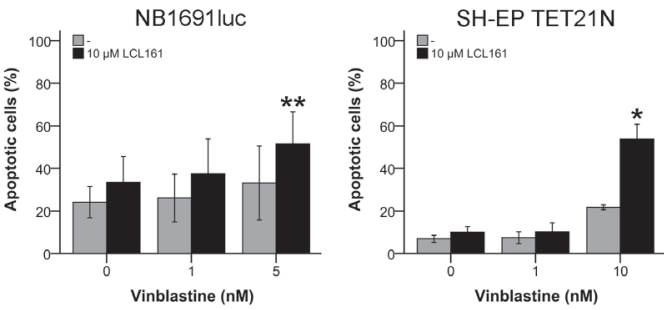

SK-N-BE(2)-M17
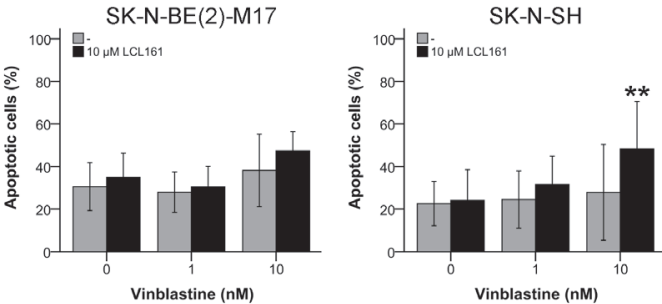

Vincristine
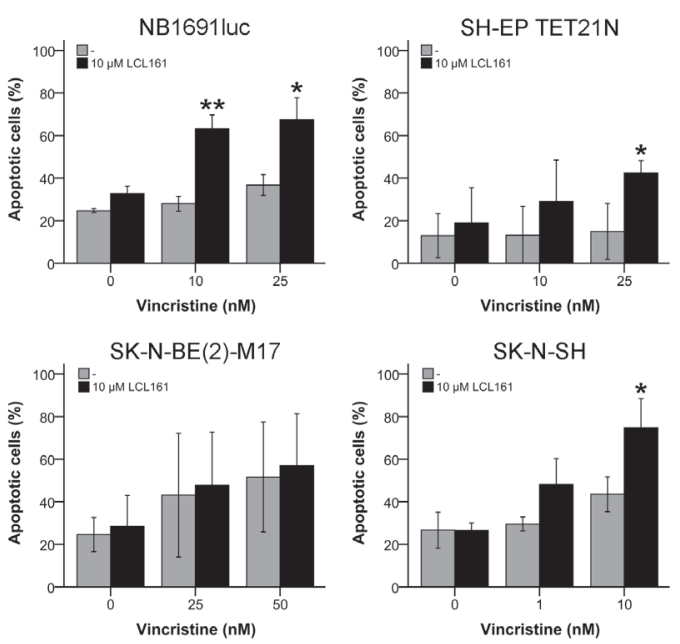

Vindesine
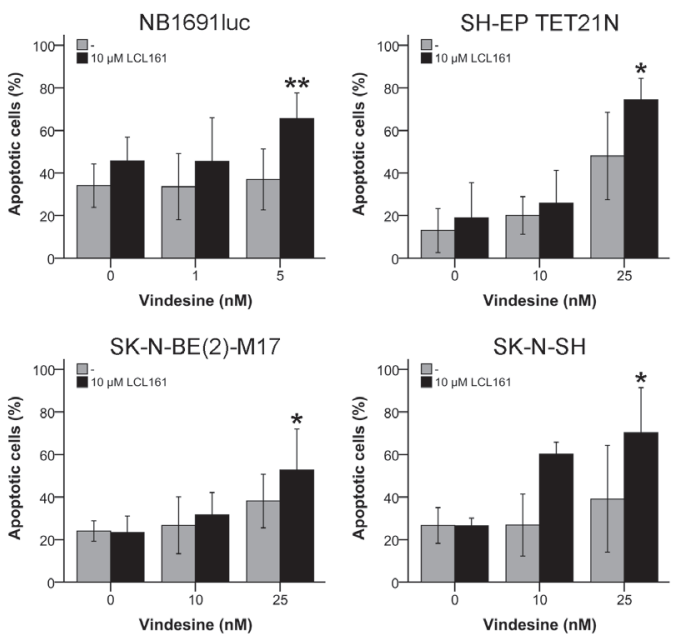

Figure 5: Induction of apoptosis in neuroblastoma cell lines by vinca alkaloids and their combination with LCL161. Cells were treated with the indicated concentrations of LCL161, vinblastine A., vincristine B. or vindesine C. and the proportion of apoptotic cells was determined by flow cytometry (Annexin V and PI staining) after $48 \mathrm{~h}$. Values represent the mean \pm SD of three independent experiments, $* ; p \leq 0.05, * * ; \leq 0.01$. 
A
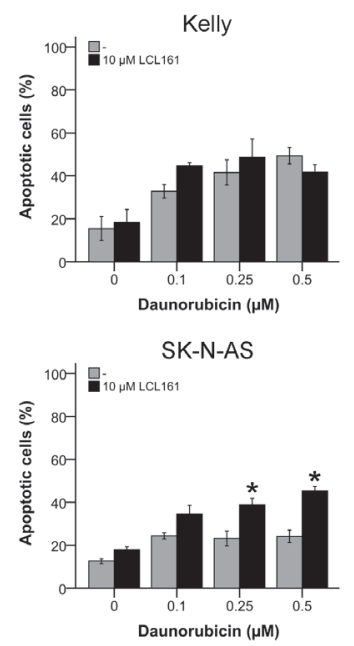

B

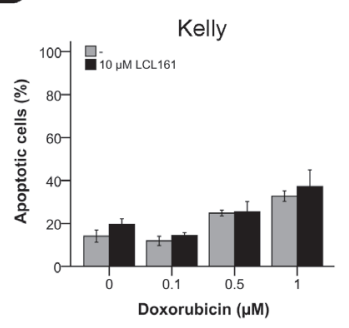

SK-N-AS

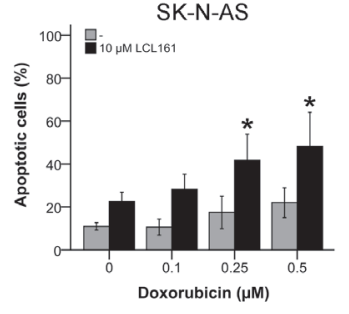

C

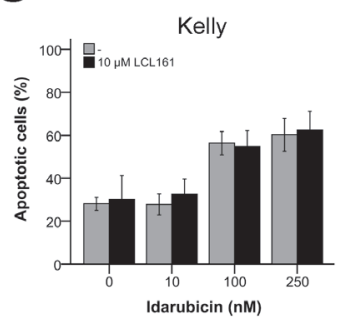

SK-N-AS

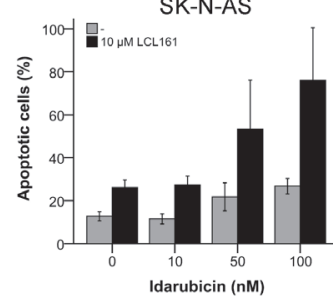

Daunorubicin
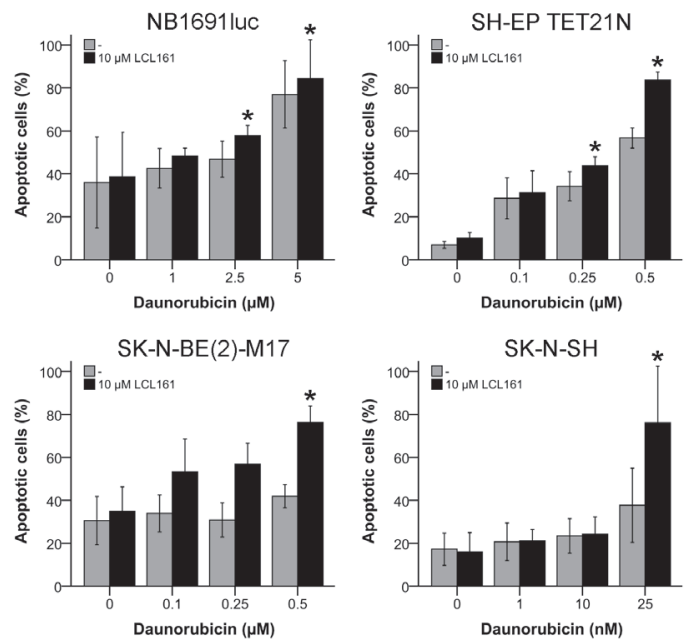

Doxorubicin
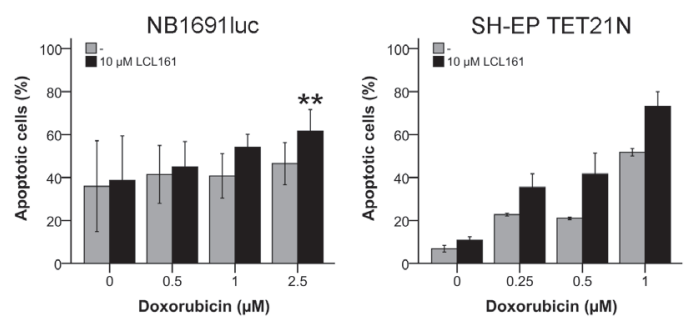

SK-N-BE(2)-M17
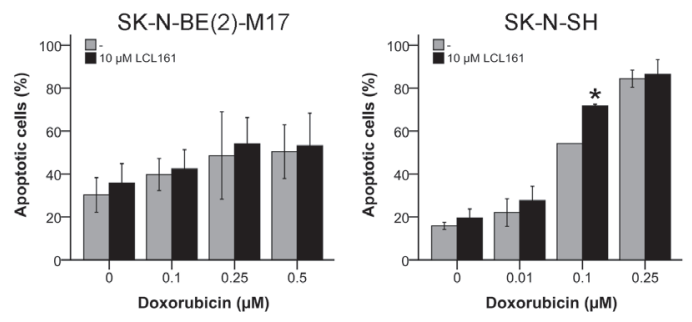

Idarubicin
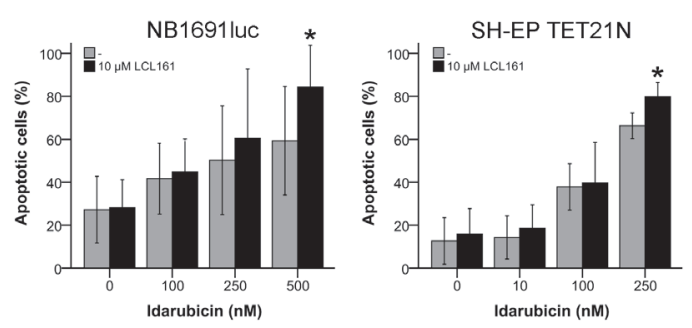

SK-N-BE(2)-M17

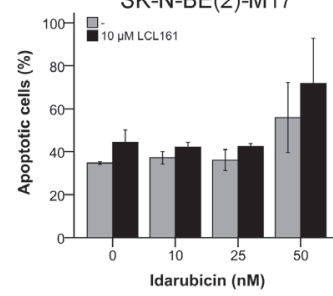

SK-N-SH

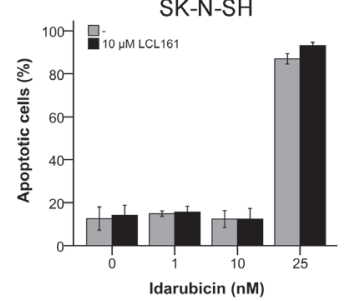

Figure 6: Induction of apoptosis in neuroblastoma cell lines by anthracyclines and their combination with LCL161. Cells were treated with the indicated concentrations of LCL161, daunorubicin A., doxorubicin B. or idarubicin C. and the proportion of apoptotic cells was determined by flow cytometry (Annexin V and PI staining) after $48 \mathrm{~h}$. Values represent the mean \pm SD of three independent experiments, $* ; p \leq 0.05, * * ; p \leq 0.01$. 
combination treatment. Add-on of LCL161 to idarubicin had no significant effect in the cell lines Kelly, SK-NBE(2)-M17 and SK-N-SH and only a low increase in apoptosis was seen in the cell line SH-EP TET21N (Figure 6C). In SK-N-AS and NB1691luc LCL161 augmented the idarubicin-induced apoptosis thus affirming the synergism detected before (Figure 6C).

\section{Topoisomerase inhibitor-induced apoptosis is only marginally increased by LCL161}

LCL161 had only minor influence on topoisomerase inhibitor-induced inhibition of cellular proliferation of NB cell lines. Therefore, it was of interest if apoptosis induction of this drug class can be increased by combination with SM. Only in the cell line SK-N-AS LCL161 was able to significantly increase the induced apoptosis of all topoisomerase inhibitors in line with the proliferation assays (Figures 7A-7C). In the cell line SK-N-BE(2)-M17 the effects of etoposide and SN-38 were significantly increased by LCL161 for some of the used drug concentrations (Figures 7A+7B).

\section{ALK activation affects interaction of chemotherapy and LCL161}

Molecular aberrations in neuroblastoma including amplification of MYCN, deletions of chromosome arm $1 \mathrm{p}$ (del1p) or mutations in p53 or anaplastic lymphoma kinase (ALK) are commonly found in advanced stage or relapsed tumors and are associated with an adverse outcome [21-25]. Therefore, it would be highly relevant to elucidate if and how these alterations (Table 2) could have an influence on sensitization of neuroblastoma cell lines for chemotherapy by LCL161.

For this reason, genetic features of NB cell lines were correlated to combination index (CI) scores reflecting synergistic $(\mathrm{CI}<1)$ or additive/antagonistic $(\mathrm{CI}$ $\geq 1$ ) interaction of chemotherapeutic drugs with LCL161 (Tables 1B and 2).

Using the Mann-Whitney $U$ test it became evident that status of MYCN, deletion of chromosome arm 1p or mutated p53 could not account for significant differences between groups (data not shown). In contrast, in cell lines with activating mutation of $\operatorname{ALK}\left(\mathrm{ALK}_{\mathrm{F} 1174 \mathrm{~L}}\right)$ a significantly higher CI than in $\mathrm{ALK}_{\mathrm{wt}}$ cells was observed for LCL161 and its combination with idarubicin (CI( $\left.\mathrm{IC}_{50}\right)$ 1.1 vs. $0.76, p=0.05)$ or SN-38 $\left(\mathrm{CI}\left(\mathrm{IC}_{50}\right) 0.94\right.$ vs. $0.8, p$ $=0.05)$ (Figure $8 \mathrm{~A})$. The largest CI difference $\left(\mathrm{ALK}_{\mathrm{F} 1174 \mathrm{~L}}\right.$ vs. $\mathrm{ALK}_{\mathrm{wt}}$ ) was detectable for doxorubicin and LCL161 $\left(\mathrm{CI}\left(\mathrm{IC}_{50}\right) 0.8\right.$ vs. $\left.0.46, p=0.127\right)$.

Cells were treated with TEA684 leading to specific inhibition of ALK phosphorylation (Figure S3) and its downstream targets to determine if the aberrant activation of ALK in the NB cell lines Kelly, SH-EP TET21N and
SK-N-SH directly influences chemotherapeutic drugs and their interaction with LCL161 [26]. Proliferation of neuroblastoma cell lines $(n=6)$ was efficiently inhibited using a low micromolar range of TAE684 ( $\mathrm{IC}_{50}$ 0.125.37 $\mu \mathrm{M}$, Figure $8 \mathrm{~B}$ and Table S1A). No significant differences were observed between $\mathrm{ALK}_{\mathrm{wt}}$ and $\mathrm{ALK}_{\mathrm{F} 1174 \mathrm{~L}}$ cells. For subsequent experiments TAE684 was used at a concentration of $1 \mathrm{nM}$, inducing no relevant antiproliferative effects.

Doxorubicin, as one of the standard drugs used in neuroblastoma chemotherapy, was selected for evaluating if ALK inhibition influences the combination of chemotherapy with Smac mimetic LCL161. Cellular proliferation was suppressed by TAE684 in all cell lines leading to enhanced doxorubicin-induced growth inhibition (Figure 8C and Table S1A). Combination of LCL161 with doxorubicin induced a synergistic antiproliferative effect in all cell lines with $\mathrm{ALK}_{\mathrm{wt}}$. Cell lines harboring mutation $\mathrm{ALK}_{\mathrm{F} 1174 \mathrm{~L}}$ were again less susceptible and showed no synergism (Figures $8 \mathrm{C}+8 \mathrm{D}$ and Tables S1A+S1B).

Simultaneous inhibition of ALK with TAE684 in doxorubicin and LCL161-treated cells had a relevant effect only in $\mathrm{ALK}_{\mathrm{F} 1174 \mathrm{~L}}$ cells (Figure 8C and Table $\mathrm{S} 1 \mathrm{~A})$. In all three $\mathrm{ALK}_{\mathrm{F} 1174 \mathrm{~L}}$ cell lines TAE684 caused a strong increase in inhibition of proliferation leading to a significant decrease of the $\mathrm{CI}\left(\mathrm{IC}_{50}\right)$ to the synergistic range (Figure 8D and Table S1B). In contrast, TAE684 only marginally influenced the impact of doxorubicin and LCL161 in cells with $\mathrm{ALK}_{\mathrm{wt}}$ and thus no relevant changes of the $\mathrm{CI}\left(\mathrm{IC}_{50}\right)$ were observed (Figures $8 \mathrm{C}+8 \mathrm{D}$ and Tables $\mathrm{S} 1 \mathrm{~A}+\mathrm{S} 1 \mathrm{~B})$.

ALK $_{\text {F1174L }}$ SH-EP TET21N cells were most susceptible for TAE684-treatment and were therefore analyzed for apoptosis induction. Treatment with 1 nM TAE684 had only marginal effects on apoptosis. In contrast, the effect of combined doxorubicin and LCL161 was significantly reinforced by TAE684. This was reflected by an increase of early (Annexin $\mathrm{V}$ positive) and late apoptotic (Annexin $\mathrm{V}$ and propidium iodide positive) cells (Figure 8E).

These findings show that TAE684-induced inhibition of activated ALK $\left(\mathrm{ALK}_{\mathrm{F} 1174 \mathrm{~L}}\right)$ in neuroblastoma not only is effective to increase the effect of chemo drugs but also is able to synergistically interact with Smac mimetic LCL161. The latter is highly relevant for cells that are resistant for combination of either TAE684 or LCL161 with chemotherapy.

\section{DISCUSSION}

Prognosis for stage 4 high-risk neuroblastoma is still poor albeit significant improvements in therapy were established that supplement high-dose chemotherapy and irradiation with innovative measures as immunotherapy [3]. We have shown that Smac mimetics (SM) are a 
A
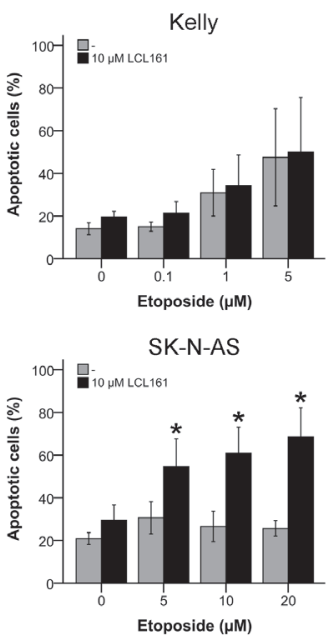

B
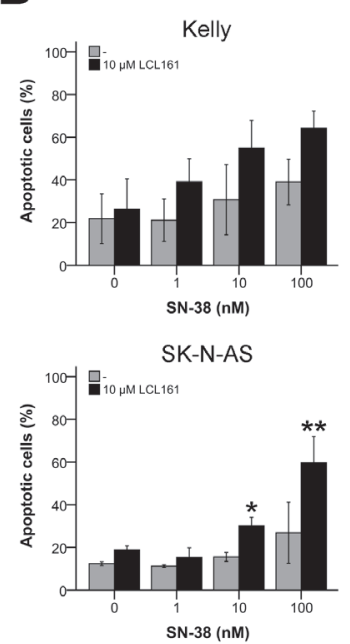

C
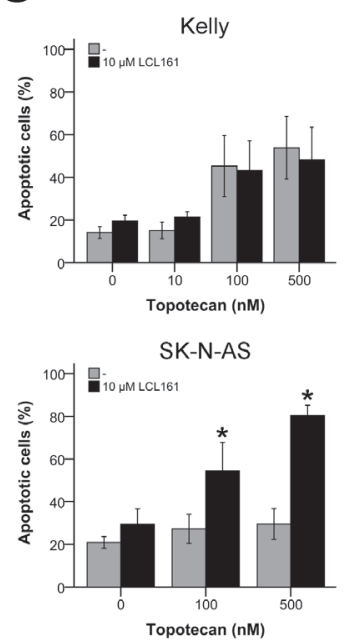

Etoposide
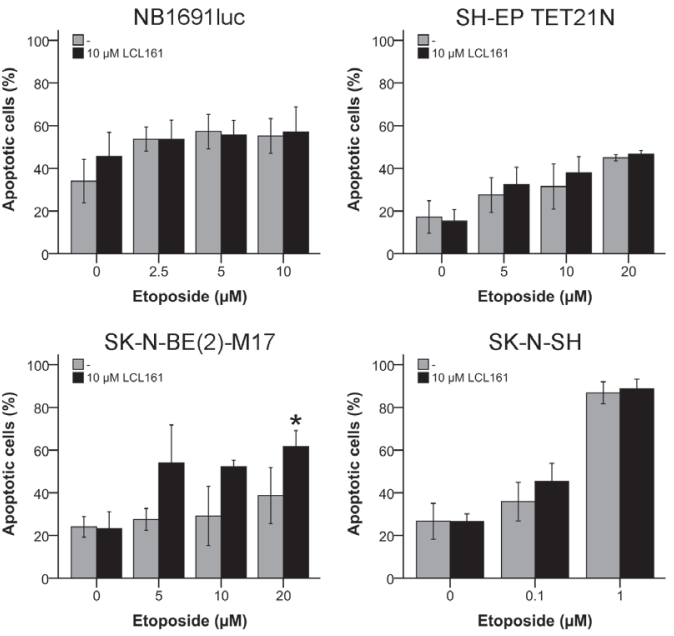

SN-38
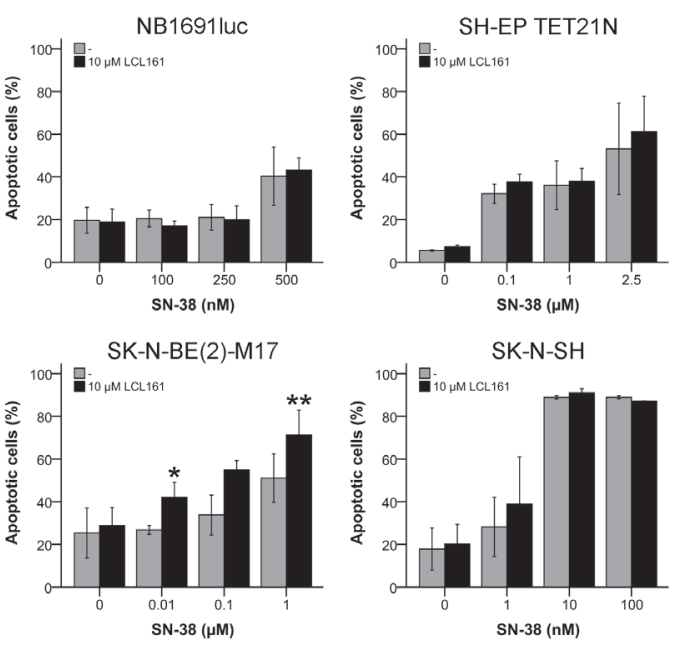

Topotecan
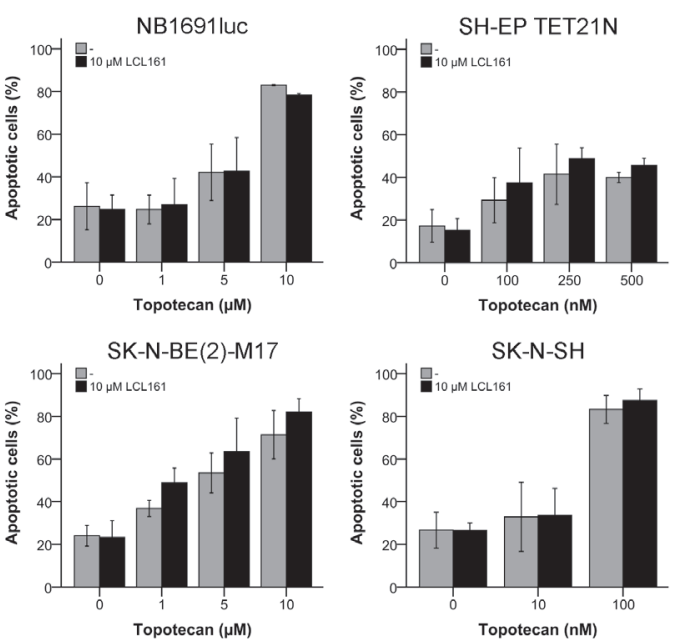

Figure 7: Induction of apoptosis in neuroblastoma cell lines by topoisomerase inhibitors and their combination with LCL161. Cells were treated with the indicated concentrations of LCL161, etoposide A., SN-38 B. or topotecan C. and the proportion of apoptotic cells was determined by flow cytometry (Annexin V and PI staining) after $48 \mathrm{~h}$. Values represent the mean $\pm \mathrm{SD}$ of three independent experiments, *; $p \leq 0.05, * * ; p \leq 0.01$. 
promising option to overcome chemoresistance [7]. However, general synergism was only achieved with vincristine.

Using a panel of NB cell lines $(n=8)$ and 3 drugs of each class of chemotherapeutics it became apparent that vinca alkaloids generally showed a synergism and significant increase in apoptosis induction with SM LCL161 (Tables 1A+1B and Figures 2, 5 and S2). Vinca alkaloids are antimitotic agents that at high concentrations (e.g. 10-100 nM in HeLa cells) prevent microtubules to polymerize thereby impede the formation of the spindle apparatus necessary for cell division [27].

In contrast, taxanes and other antimitotic agents stabilize microtubules and thus arrest the mitotic process [28].

Further analysis disclosed an activation of the $\mathrm{NF}-\kappa \mathrm{B}$ pathway by vinca alkaloids and a reduced vinca alkaloid-induced apoptosis if activation of $\mathrm{NF}-\kappa \mathrm{B}$

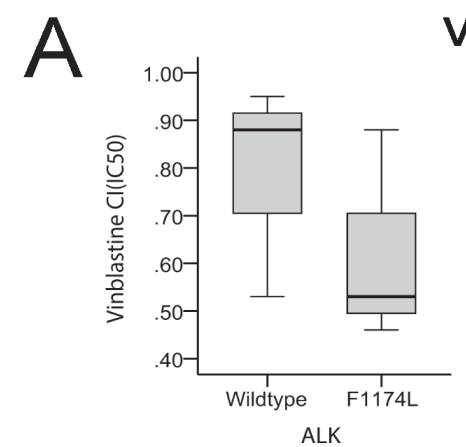

Vinca alkaloids + LCL161
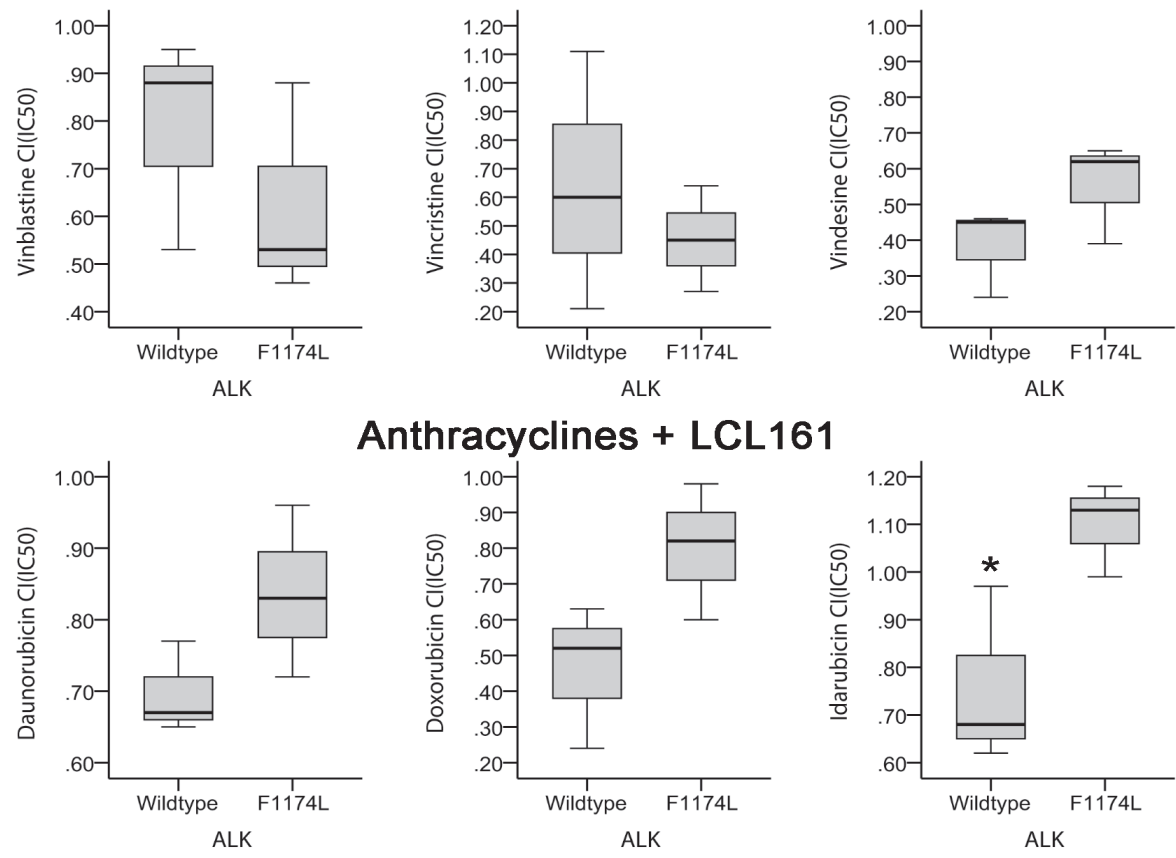

Anthracyclines + LCL161
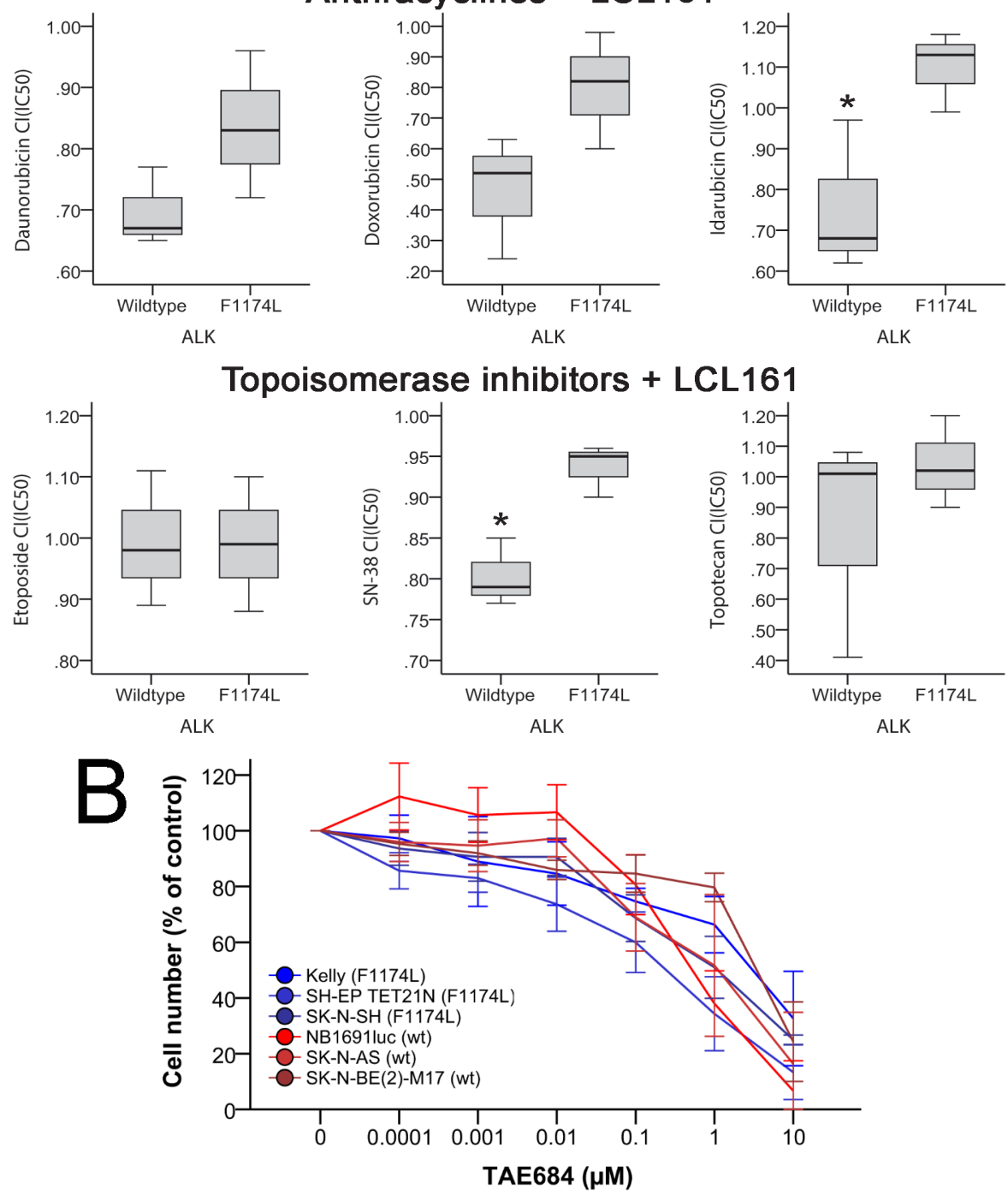
C

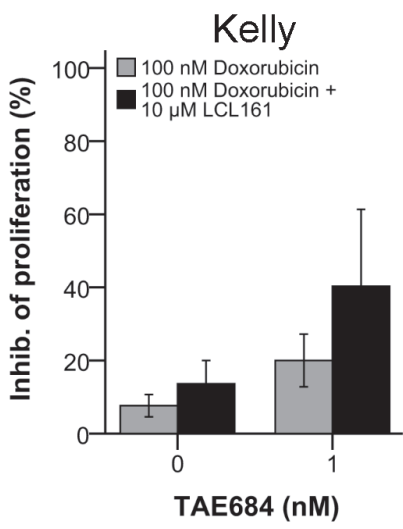

NB1691luc

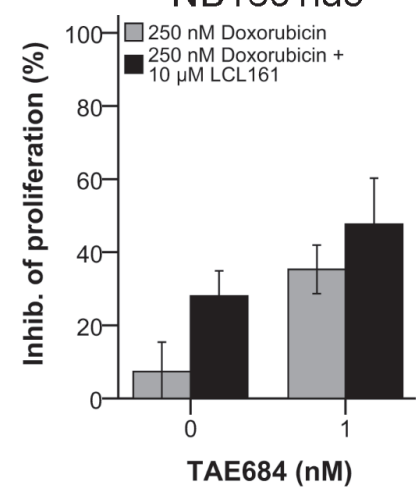

ALK Inhibition
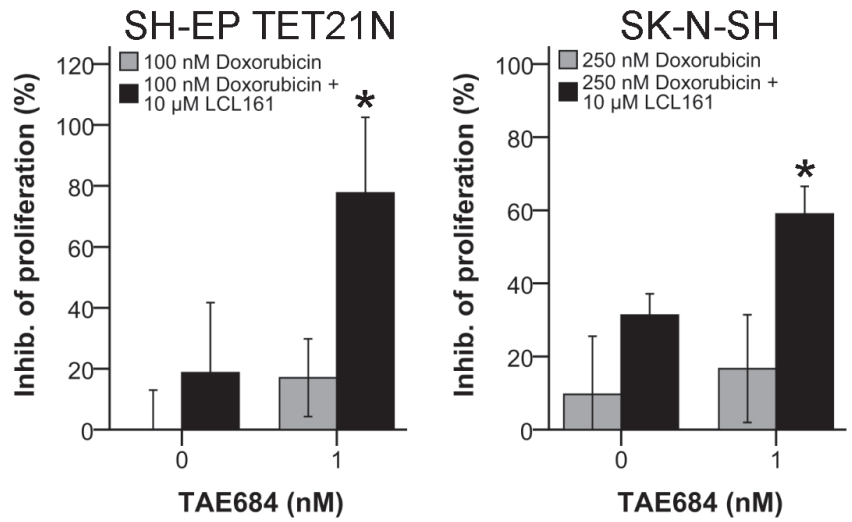

SK-N-AS

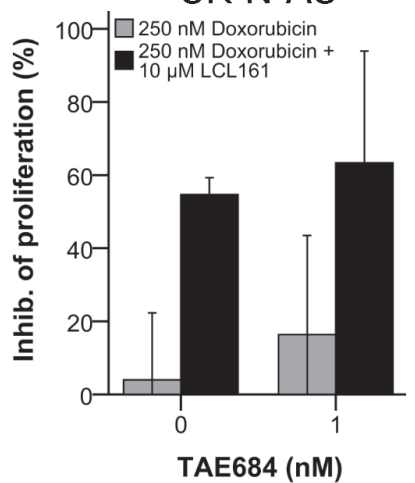

SK-N-BE(2)-M17

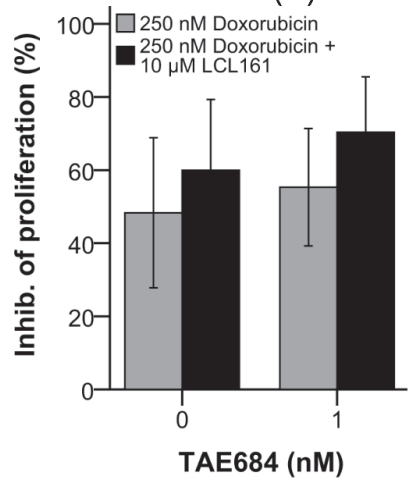

D
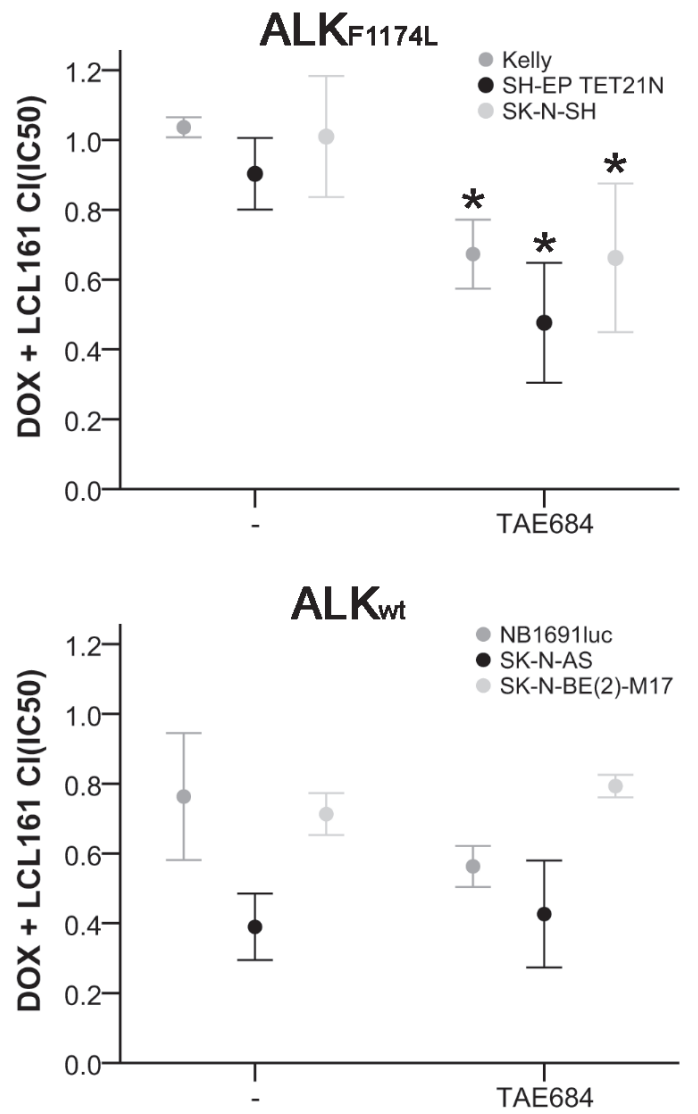

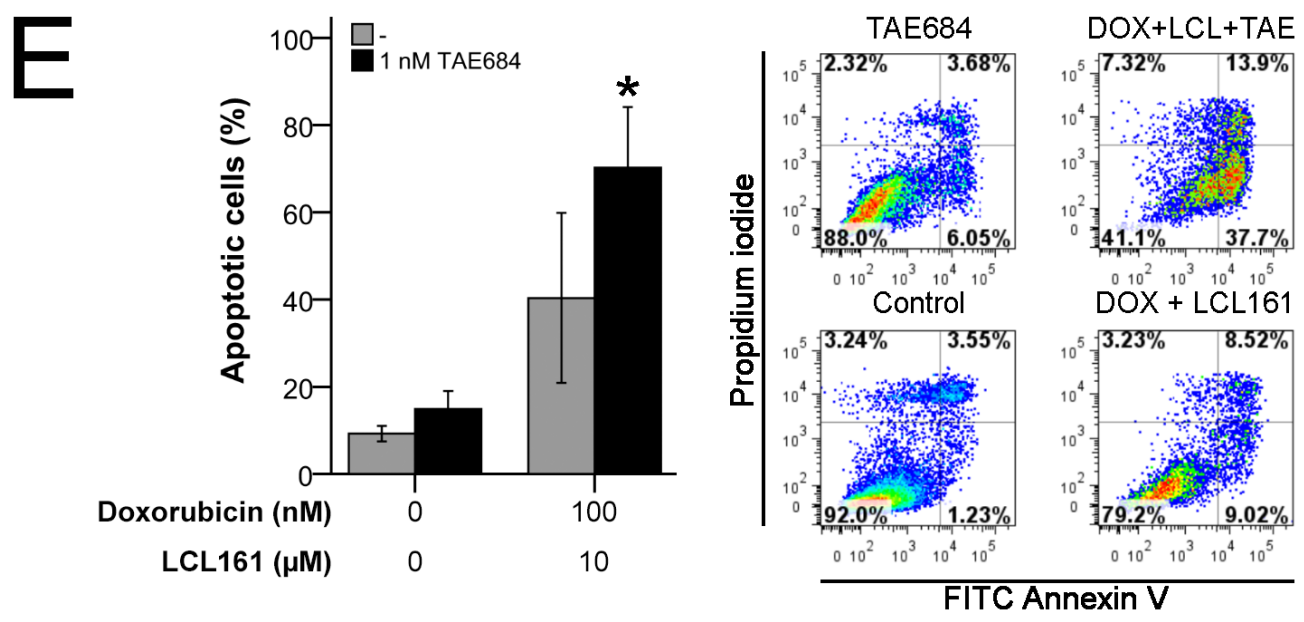

Figure 8: Activating ALK mutation F1174L influences impact of LCL161 and chemotherapy in neuroblastoma. ALK status $\left(\mathrm{ALK}_{\mathrm{wt}}\right.$ vs. $\left.\mathrm{ALK}_{\mathrm{F} 1174 \mathrm{~L}}\right)$ was correlated to combination index $(\mathrm{CI})$ scores reflecting synergistic $(\mathrm{CI}<1)$ or additive/antagonistic $(\mathrm{CI} \geq$ 1) interaction of chemotherapeutic drugs with LCL161 A.. Box plots represent the interquartile range (25-75th percentile) and the median value (black line). Whiskers represent the maximum and minimum values, respectively. Proliferation of cells treated with the indicated concentrations of TAE684 was determined after 48h B.. Proliferation of untreated cells was defined as $100 \%$. Cells were treated with the indicated concentrations of doxorubicin, LCL161 or TAE684 and inhibition of proliferation was determined after 48h C.. Inhibition of proliferation of untreated cells was defined as $0 \%$. IC50 values for dose-effect curves were determined and taken as a basis for the calculation of combination indices (CI) D.. SH-EP TET21N cells were treated with the indicated concentrations of doxorubicin, LCL161 or TAE684 and the proportion of apoptotic cells was determined by flow cytometry (Annexin V and PI staining) after $48 \mathrm{~h}$ E.. Dot plots are representative for the performed analyses. Values represent the mean $\pm \mathrm{SD}$ of three independent experiments B.-E., *; $p \leq 0.05$.

pathway was impeded. NF- $\mathrm{kB}$ signaling is involved in the regulation of a manifold of cellular processes and has shown to either induce or block apoptosis dependent on the cellular context [29].

Modulation of NF- $\mathrm{kB}$ signaling by vinca alkaloids might be one explanation why these class of chemotherapeutics showed such a remarkable potency if combined with Smac mimetics.

Apoptosis induction by SM originally was thought to be solely mediated by direct binding to XIAP and abrogation of its inhibition of caspase activation [10]. Recently the degradation of cIAP-1/-2 and the subsequent activation of NF- $\mathrm{KB}$ and induction of TNF- $\alpha$ was proposed as the main molecular effect of SM in tumor cells [1820]. TNF- $\alpha$ was found to be crucial for synergism of SM with chemotherapy by activating the extrinsic apoptotic pathway [30].

Nevertheless, this model does not seem to be generally valid for neuroblastoma as we could show that neuroblastoma cells were sensitized by SM LBW242 independent of TNF- $\alpha$ [7]. Apoptosis induction in neuroblastoma cell lines using SM BV6 recently has also been demonstrated to be independent of TNF- $\alpha$ signaling [31] Additionally there is evidence that other pathways involving RIP1 could be crucial for SMmediated sensitization for chemotherapy as well [32]. In neuroblastoma RIP1 has shown to be required for apoptosis induction only for the combination of BV6 and doxorubicin but not for BV6 and vincristine [31]. This was explained by activation of different initial cellular programs by the used drug.
SM LBW242 synergistically increased impact of treatment of neuroblastoma with the anthracycline drug doxorubicin in three of four cell lines [7].

We now showed that the anthracyclines daunorubicin and doxorubicin synergistically interacted with LCL161 in all except one cell line (Tables 1A+1B and Figures $3 \mathrm{~A}+3 \mathrm{~B}$ ). In contrast, with idarubicin only in two cell lines a synergism was detectable (Tables $1 \mathrm{~A}+1 \mathrm{~B}$ and Figure 3C).

The mechanisms of action that are responsible for cell death induction by anthracyclines are still ambiguous. DNA intercalation leading to inhibition of DNA transcription and replication and more relevant poisoning of topoisomerase II leading to aggregation of damaged DNA, G1/G2 cell cycle arrest and apoptosis were described for anthracyclines to name just a few [33$35]$.

Cytotoxic eviction of histones and formation of free radicals are other mechanism that obviously are relevant for the anti-tumor effects of anthracyclines [36-38].

The high homology between doxorubicin and daunorubicin, which only differ in a hydroxy group, most likely accounts for the similar effects that were observed in combination with LCL161. Idarubicin is derived from daunorubicin by elimination of a methoxy group resulting in an increased lipophility and better uptake into the cell [39].

SM LBW242-treatment did not significantly increase topoisomerase inhibitor etoposide-induced inhibition of proliferation in neuroblastoma cell lines [7]. Combination of SM LCL161 with etoposide, SN-38 
or topotecan now indicated a predominant insensitivity against topoisomerase inhibitors, if compared with clinically reachable concentrations, that can be overcome by LCL161 only in a minority of the cells (Tables $1 \mathrm{~A}+1 \mathrm{~B}$ and Figures 2, 6 and S2).

Drug resistance during recurrent disease is a major problem in the treatment of cancer [40].

For etoposide it was demonstrated that neuroblastoma cell lines obtained at time of diagnosis were sensitive for etoposide but that resistance obviously was acquired during progressive disease or if disease relapsed [41].

With this in mind it is not surprising that the $\mathrm{IC}_{50}$ (4.6-29.1 $\mu \mathrm{M})$ of almost all (7 of 8) tested NB cell lines were much higher as the achievable plasma steady-state concentration of $\sim 12 \mu \mathrm{M}(7 \mu \mathrm{g} / \mathrm{ml})$ as only one cell line was established before therapy [42].

A comparable pattern of resistance was seen for $\mathrm{SN}-38\left(\mathrm{IC}_{50} 13 \mathrm{nM}-1.56 \mu \mathrm{M}\right.$ vs. $\mathrm{C}_{\max }$ of $56 \mathrm{nM}(22 \mathrm{ng} /$ $\mathrm{ml})$ ) [43] and topotecan $\left(\mathrm{IC}_{50} 80 \mathrm{nM}-1.17 \mu \mathrm{M}\right.$ vs. $\mathrm{C}_{\max }$ of $209 \mathrm{nM}(88 \mathrm{ng} / \mathrm{ml}))$ [44]. Cross-resistance of SN-38 and topotecan with etoposide is another problem that was observed after intensive chemotherapy and use of topoisomerase inhibitors during recurrent disease was thus not suggested [45].

The use of Smac mimetics in contrast could nevertheless be a promising strategy to overcome topoisomerase inhibitor resistance in some cases. The cell line SK-N-AS disclosed triple resistance against etoposide $\left(\mathrm{IC}_{50} 26.7 \mu \mathrm{M}\right), \mathrm{SN}-38\left(\mathrm{IC}_{50} 0.53 \mu \mathrm{M}\right)$ and topotecan $\left(\mathrm{IC}_{50}\right.$ $0.78 \mu \mathrm{M})$ but all drugs showed a synergism with LCL161. This synergism lowered the $\mathrm{IC}_{50}$ to $20.4 \mu \mathrm{M}$ for etoposide, to $0.38 \mu \mathrm{M}$ for $\mathrm{SN}-38$ and to $0.22 \mu \mathrm{M}$ for topotecan. As these concentrations are only clinically achievable for topotecan, it would however have relevant clinical implications to find molecular markers that are causal for these findings.

Systematical analysis of susceptibility of different drug classes for LCL161 revealed a so far unknown association with mutation of $\mathrm{ALK} \quad\left(\mathrm{ALK}_{\mathrm{F} 1174 \mathrm{~L}}\right)$. Interestingly, other molecular aberrations like MYCN status did not influence impact of LCL161. Point mutations activating the ALK tyrosine kinase domain were found in familial and sporadic neuroblastomas with high frequency [26, 46-48].

In neuroblastoma the most common and aggressive modified ALK variant $\left(\mathrm{ALK}_{\mathrm{F} 1174 \mathrm{~L}}\right)$ is necessary for cellular proliferation and survival [26]. Furthermore, $\mathrm{ALK}_{\mathrm{F} 1174 \mathrm{~L}}$ targeted expression has been demonstrated to be tumorigenic in mice inducing neuroblastomas that resemble the human disease [49]. Transgenic $\mathrm{ALK}_{\mathrm{F} 1174 \mathrm{~L}}$ mice were dependent on $\mathrm{ALK}_{\mathrm{F} 1174 \mathrm{~L}}$ activity as treatment with ALK inhibitor TAE684 induced a complete tumor regression.

Consequently, we could show that inhibition of ALK using TAE684 induces a significant decrease in cellular proliferation of neuroblastoma cell lines (Figure 8B).

For the first time we demonstrated that SM LCL161 positively interacted with TAE684 (Figures $8 \mathrm{C}+8 \mathrm{D}$ ), while exhibiting minor effects only together with doxorubicin in $\mathrm{ALK}_{\mathrm{F} 1174 \mathrm{~L}}$ cells (Figures 3B and 8C+8D).

Combined inhibition of ALK using TAE684 however was able to overcome LCL161-resistance leading to a synergistic inhibition of cell growth (Figures 8C+8D).

In contrast, in $\mathrm{ALK}_{\mathrm{wt}}$ cells the effects of LCL161 and doxorubicin were not significantly increased by TAE684.

This is in line with other findings that showed a stronger impact of TAE684 on $\mathrm{ALK}_{\mathrm{F} 1174 \mathrm{~L}}$ than $\mathrm{ALK}_{\mathrm{wt}}$ $[26,50]$. Activated ALK controls a manifold of pathways including phosphatidylinositol-3 kinase (PI3K) signaling [51]. Activated PI3K in turn activates Akt that is directly involved in regulation of apoptosis. XIAP phosphorylation by Akt protects XIAP from cisplatininduced ubiquitination and degradation thus preventing apoptosis induction [52]. In pancreatic cancer cells, which were resistant for SM AZD5582, knockdown of Akt using RNAi sensitized them for AZD5582 [53]. Moreover, extent of AZD5582-induced apoptosis was dependent on the expression levels of $\mathrm{p}$-Akt and p-XIAP.

Taken together a hypothesis evolves that would give a molecular basis for the observed synergism of TAE684 and LCL161 in ALK $_{\mathrm{F} 1174 \mathrm{~L}}$ neuroblastoma. Elevated XIAP levels and XIAP stabilization by $\mathrm{ALK}_{\mathrm{F} 1174 \mathrm{~L}} /$ PI3K/Akt-mediated phosphorylation would potentially confer a strong resistance against apoptotic stimuli. On this background, inhibition of ALK by TAE684 would destabilize XIAP by preventing its phosphorylation by Akt. LCL161-treatment would disturb XIAP interaction and inhibition of caspases. Both TAE684 and LCL161 have the potential to induce apoptosis but are especially effective in supporting other apoptotic stimuli. In combination, their impact on XIAP is further increased leading to a considerable gain of chemotherapy.

In summary, ALK inhibition together with SM LCL161 could be a highly effective option to significantly augment chemotherapy by synergistically suppressing inhibitor of apoptosis proteins.

\section{MATERIALS AND METHODS}

\section{Cell lines and cell culture}

Neuroblastoma cell lines Kelly, NB1691luc, SHEP TET21N, SK-N-AS, SK-N-BE(2)-M17 and SK$\mathrm{N}-\mathrm{SH}$ as well as recently established de novo cell lines HGW-1 and HGW-3 (kindly provided by Holger Lode; University Medicine Greifswald) [54] were used. The SH-EP TET21N system is a conditional, tetracyclineregulated MYCN expression system established in the SH-EP neuroblastoma cell line [55]. NB1691luc are 
luciferase-expressing, zeocin-resistant NB1691 cells [56]. Neuroblastoma cells were maintained in RPMI 1640 or IMDM medium (HGW-1 and HGW-3) supplemented with 10-20\% fetal bovine serum (both Life Technologies, Darmstadt, Germany), penicillin/streptomycin (10.000 $\mathrm{U} / \mathrm{ml} / 10.000 \mathrm{~g} / \mathrm{ml}$, Biochrom, Berlin, Germany) and zeocin $(100 \mu \mathrm{g} / \mathrm{ml}$; NB1691luc). All cells were cultivated at $37^{\circ} \mathrm{C}, 5 \% \mathrm{CO}_{2}$-atmosphere and a relative humidity of $95 \%$.

\section{Chemical compounds, biological reagents and drugs}

Novartis Pharma generously provided Smac mimetic LCL161. Cytostatic drugs daunorubicin, doxorubicin, etoposide, idarubicin, topotecan, SN-38 (active metabolite of irinotecan), vinblastine, vincristine and vindesine were obtained from Sigma-Aldrich (Munich, Germany). NVP-TAE684 was purchased from Selleckchem (Munich, Germany). Working solutions were prepared by dilution of drugs with medium or $\mathrm{ddH}_{2} \mathrm{O}$ to designated concentrations.

\section{Protein extraction and Western blot analysis}

Cell lysates were prepared with radioimmunoprecipitation assay (RIPA) buffer (SigmaAldrich) supplemented with Complete protease inhibitor cocktail and PhosSTOP - Phosphatase Inhibitor Cocktail (Roche). Standard procedures for Western blotting were followed using the following primary antibodies: cIAP1 (AF8181; R\&D), XIAP (610762; BD Biosciences) and $\beta$-actin (A1978; Sigma-Aldrich). Specific protein bands were visualized using IRDye $680 \mathrm{RD}$ or $800 \mathrm{CW}$ secondary antibodies (LI-COR) and LI-COR Odyssey infrared imaging system.

\section{Total ALK and Phospho-ALK ELISA}

Expression of total ALK and phospho-ALK was quantified using PathScan ${ }^{\circledR}$ Total ALK and PhosphoALK (Tyr1604) Chemiluminescent Sandwich ELISA Kits (7084C and 7020C, Cell Signaling) according to the manufacturer's protocols. Protein concentrations of lysates were determined using Bio-Rad Protein Assay and bovine serum abumin as protein standard.

\section{Cellular proliferation assays}

Proliferation assays were performed with Cell Proliferation Reagent WST-1 (Roche, Grenzach, Germany) according to the manufacturer's protocol. Cells were seeded in culture medium in 96-well plates to adhere overnight. Cytostatic drugs and LCL161 were added to the cells for an incubation period of 48 hours. Following incubation with WST-1 for 2 hours, absorbance was measured with an ELISA reader. $\mathrm{IC}_{50}$ values were determined using in-house software (Microsoft Excel).

\section{Detection of apoptosis by flow cytometry}

Cells were seeded in cell culture medium in 24well plates to adhere overnight. Cells were treated with the indicated reagents for $48 \mathrm{~h}$. Cells were harvested, washed twice with PBS and resuspended in Annexin V binding buffer (10 mM Hepes, $140 \mathrm{mM} \mathrm{NaCl}$, and 0.25 $\mathrm{mM} \mathrm{CaCl} 2$ ). Apoptosis was detected by Annexin V-FITC (556419; BD Pharmingen, Heidelberg, Germany) and propidium-iodide (PI) $\left(1 \mathrm{mg} / \mathrm{ml}\right.$ in $\mathrm{ddH}_{2} \mathrm{O}$; Invitrogen, Darmstadt, Germany) staining and flow cytometry.

\section{Statistical analysis}

Combination indices (CI) for cellular proliferation assays were calculated using the Chou-Talay method to determine synergism $(\mathrm{CI} \leq 0.9)$, additivity $(\mathrm{CI}>0.9-1.1)$, or antagonism (CI > 1.1), if combining LCL161 with cytostatic drugs [57]. The CI was calculated according to the classic isobologram equation: $\mathrm{CI}=(d 1 / D 1)+(d 2 / D 2)$, where D1 and D2 represent the required doses of drug 1 and 2 to produce $\mathrm{x} \%$ effect and $\mathrm{d} 1$ and $\mathrm{d} 2$ the required doses of drug 1 and 2 to produce the same effect if used in combination. Statistical significance of differences between experimental groups was determined using the Student $t$-test or the Mann-Whitney $U$ test. A two tailed $p$-value $\leq 0.05$ was regarded as significant.

\section{ACKNOWLEDGMENTS}

We thank the FACS Sorting Core Unit of the University Medical Center Hamburg-Eppendorf for their excellent technical support.

\section{CONFLICTS OF INTEREST}

The authors have no conflicts of interests

\section{REFERENCES}

1. Park JR, Bagatell R, London WB, Maris JM, Cohn SL, Mattay KM and Hogarty M. Children's Oncology Group's 2013 blueprint for research: neuroblastoma. Pediatric blood \& cancer. 2013; 60:985-993.

2. Pinto NR, Applebaum MA, Volchenboum SL, Matthay KK, London WB, Ambros PF, Nakagawara A, Berthold F, Schleiermacher G, Park JR, Valteau-Couanet D, Pearson $\mathrm{AD}$ and Cohn SL. Advances in Risk Classification and Treatment Strategies for Neuroblastoma. Journal of clinical 
oncology. 2015; 33:3008-3017.

3. Yu AL, Gilman AL, Ozkaynak MF, London WB, Kreissman SG, Chen HX, Smith M, Anderson B, Villablanca JG, Matthay KK, Shimada H, Grupp SA, Seeger R, Reynolds $\mathrm{CP}$, Buxton A, Reisfeld RA, et al. Anti-GD2 antibody with GM-CSF, interleukin-2, and isotretinoin for neuroblastoma. NEnglJMed. 2010; 363:1324-1334.

4. Maris JM. Recent advances in neuroblastoma. NEnglJMed. 2010; 362:2202-2211.

5. Simon T, Berthold F, Borkhardt A, Kremens B, De CB and Hero B. Treatment and outcomes of patients with relapsed, high-risk neuroblastoma: results of German trials. PediatrBlood Cancer. 2011; 56:578-583.

6. Hanahan D and Weinberg RA. The hallmarks of cancer. Cell. 2000; 100:57-70.

7. Eschenburg G, Eggert A, Schramm A, Lode HN and Hundsdoerfer P. Smac mimetic LBW242 sensitizes XIAP-overexpressing neuroblastoma cells for TNF-alphaindependent apoptosis. Cancer research. 2012; 72:26452656.

8. Hundsdoerfer P, Dietrich I, Schmelz K, Eckert C and Henze G. XIAP expression is post-transcriptionally upregulated in childhood ALL and is associated with glucocorticoid response in T-cell ALL. PediatrBlood Cancer. 2010; 55:260-266.

9. Hunter AM, Lacasse EC and Korneluk RG. The inhibitors of apoptosis (IAPs) as cancer targets. Apoptosis. 2007; 12:1543-1568.

10. Lacasse EC, Mahoney DJ, Cheung HH, Plenchette S, Baird $\mathrm{S}$ and Korneluk RG. IAP-targeted therapies for cancer. Oncogene. 2008; 27:6252-6275.

11. Holcik M and Korneluk RG. XIAP, the guardian angel. NatRevMolCell Biol. 2001; 2:550-556.

12. Du C, Fang M, Li Y, Li L and Wang X. Smac, a mitochondrial protein that promotes cytochrome c-dependent caspase activation by eliminating IAP inhibition. Cell. 2000; 102:33-42.

13. Fulda S. Inhibitor of apoptosis proteins in hematological malignancies. Leukemia. 2009; 23:467-476.

14. Weisberg E, Ray A, Barrett R, Nelson E, Christie AL, Porter D, Straub C, Zawel L, Daley JF, Lazo-Kallanian S, Stone R, Galinsky I, Frank D, Kung AL and Griffin JD. Smac mimetics: implications for enhancement of targeted therapies in leukemia. Leukemia. 2010; 24:2100-2109.

15. Gyrd-Hansen M and Meier P. IAPs: from caspase inhibitors to modulators of NF-kappaB, inflammation and cancer. NatRevCancer. 2010; 10:561-574.

16. Houghton PJ, Kang MH, Reynolds CP, Morton CL, Kolb EA, Gorlick R, Keir ST, Carol H, Lock R, Maris JM, Billups CA and Smith MA. Initial testing (stage 1) of LCL161, a SMAC mimetic, by the Pediatric Preclinical Testing Program. Pediatric blood \& cancer. 2012; 58:636639.

17. Infante JR, Dees EC, Olszanski AJ, Dhuria SV, Sen S,
Cameron S and Cohen RB. Phase I dose-escalation study of LCL161, an oral inhibitor of apoptosis proteins inhibitor, in patients with advanced solid tumors. Journal of clinical oncology. 2014; 32:3103-3110.

18. Petersen SL, Wang L, Yalcin-Chin A, Li L, Peyton M, Minna J, Harran P and Wang X. Autocrine TNFalpha signaling renders human cancer cells susceptible to Smacmimetic-induced apoptosis. Cancer Cell. 2007; 12:445-456.

19. Varfolomeev E, Blankenship JW, Wayson SM, Fedorova AV, Kayagaki N, Garg P, Zobel K, Dynek JN, Elliott LO, Wallweber HJ, Flygare JA, Fairbrother WJ, Deshayes $\mathrm{K}$, Dixit VM and Vucic D. IAP antagonists induce autoubiquitination of c-IAPs, NF-kappaB activation, and TNFalpha-dependent apoptosis. Cell. 2007; 131:669-681.

20. Vince JE, Wong WW, Khan N, Feltham R, Chau D, Ahmed AU, Benetatos CA, Chunduru SK, Condon SM, McKinlay M, Brink R, Leverkus M, Tergaonkar V, Schneider P, Callus BA, Koentgen F, et al. IAP antagonists target cIAP1 to induce TNFalpha-dependent apoptosis. Cell. 2007; 131:682-693.

21. Attiyeh EF, London WB, Mosse YP, Wang Q, Winter C, Khazi D, McGrady PW, Seeger RC, Look AT, Shimada H, Brodeur GM, Cohn SL, Matthay KK and Maris JM. Chromosome $1 \mathrm{p}$ and $11 \mathrm{q}$ deletions and outcome in neuroblastoma. The New England journal of medicine. 2005; 353:2243-2253.

22. Carr-Wilkinson J, O'Toole K, Wood KM, Challen CC, Baker AG, Board JR, Evans L, Cole M, Cheung NK, Boos J, Kohler G, Leuschner I, Pearson AD, Lunec J and Tweddle DA. High Frequency of p53/MDM2/p14ARF Pathway Abnormalities in Relapsed Neuroblastoma. Clinical cancer research. 2010; 16:1108-1118.

23. De Brouwer S, De Preter K, Kumps C, Zabrocki P, Porcu M, Westerhout EM, Lakeman A, Vandesompele J, Hoebeeck J, Van Maerken T, De Paepe A, Laureys G, Schulte JH, Schramm A, Van Den Broecke C, Vermeulen J, et al. Metaanalysis of neuroblastomas reveals a skewed ALK mutation spectrum in tumors with MYCN amplification. Clinical cancer research. 2010; 16:4353-4362.

24. Huang M and Weiss WA. Neuroblastoma and MYCN. Cold Spring Harbor perspectives in medicine. 2013; 3:a014415.

25. Schleiermacher G, Javanmardi N, Bernard V, Leroy Q, Cappo J, Rio Frio T, Pierron G, Lapouble E, Combaret V, Speleman F, de Wilde B, Djos A, Ora I, Hedborg F, Trager C, Holmqvist BM, et al. Emergence of new ALK mutations at relapse of neuroblastoma. Journal of clinical oncology. 2014; 32:2727-2734.

26. George RE, Sanda T, Hanna M, Frohling S, Luther W, 2nd, Zhang J, Ahn Y, Zhou W, London WB, McGrady P, Xue L, Zozulya S, Gregor VE, Webb TR, Gray NS, Gilliland DG, et al. Activating mutations in ALK provide a therapeutic target in neuroblastoma. Nature. 2008; 455:975-978.

27. Jordan MA, Thrower D and Wilson L. Mechanism of inhibition of cell proliferation by Vinca alkaloids. Cancer research. 1991; 51:2212-2222. 
28. Jordan MA and Wilson L. Microtubules as a target for anticancer drugs. Nature reviews Cancer. 2004; 4:253-265.

29. Barkett $\mathrm{M}$ and Gilmore TD. Control of apoptosis by Rel/ NF-kappaB transcription factors. Oncogene. 1999; 18:69106924.

30. Probst BL, Liu L, Ramesh V, Li L, Sun H, Minna JD and Wang L. Smac mimetics increase cancer cell response to chemotherapeutics in a TNF-alpha-dependent manner. Cell DeathDiffer. 2010; 17:1645-1654.

31. Czaplinski S, Abhari BA, Torkov A, Seggewiss D, Hugle $M$ and Fulda S. Differential role of RIP1 in Smac mimetic-mediated chemosensitization of neuroblastoma cells. Oncotarget. 2015; 6:41522-34. doi: 10.18632/ oncotarget.6308.

32. Loder S, Fakler M, Schoeneberger H, Cristofanon $\mathrm{S}$, Leibacher J, Vanlangenakker $\mathrm{N}$, Bertrand MJ, Vandenabeele P, Jeremias I, Debatin KM and Fulda S. RIP1 is required for IAP inhibitor-mediated sensitization of childhood acute leukemia cells to chemotherapy-induced apoptosis. Leukemia. 2012; 26:1020-1029.

33. Chaires JB, Dattagupta N and Crothers DM. Studies on interaction of anthracycline antibiotics and deoxyribonucleic acid: equilibrium binding studies on interaction of daunomycin with deoxyribonucleic acid. Biochemistry. 1982; 21:3933-3940.

34. Perego P, Corna E, De Cesare M, Gatti L, Polizzi D, Pratesi G, Supino R and Zunino F. Role of apoptosis and apoptosisrelated genes in cellular response and antitumor efficacy of anthracyclines. Current medicinal chemistry. 2001; 8:31-37.

35. Tewey KM, Rowe TC, Yang L, Halligan BD and Liu LF. Adriamycin-induced DNA damage mediated by mammalian DNA topoisomerase II. Science. 1984; 226:466-468.

36. Minotti G, Menna P, Salvatorelli E, Cairo G and Gianni L. Anthracyclines: molecular advances and pharmacologic developments in antitumor activity and cardiotoxicity. Pharmacological reviews. 2004; 56:185-229.

37. Pang B, Qiao X, Janssen L, Velds A, Groothuis T, Kerkhoven R, Nieuwland M, Ovaa H, Rottenberg S, van Tellingen O, Janssen J, Huijgens P, Zwart W and Neefjes J. Drug-induced histone eviction from open chromatin contributes to the chemotherapeutic effects of doxorubicin. Nature communications. 2013; 4:1908.

38. Sorensen BS, Sinding J, Andersen AH, Alsner J, Jensen PB and Westergaard O. Mode of action of topoisomerase IItargeting agents at a specific DNA sequence. Uncoupling the DNA binding, cleavage and religation events. Journal of molecular biology. 1992; 228:778-786.

39. Recher C, Bene MC, Lioure B, Pigneux A, Vey N, Delaunay J, Luquet I, Hunault M, Guyotat D, Bouscary D, Fegueux N, Jourdan E, Lissandre S, Escoffre-Barbe M, Bonmati C, Randriamalala E, et al. Long-term results of a randomized phase 3 trial comparing idarubicin and daunorubicin in younger patients with acute myeloid leukaemia. Leukemia. 2014; 28:440-443.
40. Holohan C, Van Schaeybroeck S, Longley DB and Johnston PG. Cancer drug resistance: an evolving paradigm. Nature reviews Cancer. 2013; 13:714-726.

41. Keshelava N, Seeger RC, Groshen S and Reynolds CP. Drug resistance patterns of human neuroblastoma cell lines derived from patients at different phases of therapy. Cancer research. 1998; 58:5396-5405.

42. Bennett CL, Sinkule JA, Schilsky RL, Senekjian E and Choi KE. Phase I clinical and pharmacological study of 72-hour continuous infusion of etoposide in patients with advanced cancer. Cancer research. 1987; 47:1952-1956.

43. Negoro S, Fukuoka M, Masuda N, Takada M, Kusunoki Y, Matsui K, Takifuji N, Kudoh S, Niitani H and Taguchi T. Phase I study of weekly intravenous infusions of CPT11, a new derivative of camptothecin, in the treatment of advanced non-small-cell lung cancer. Journal of the National Cancer Institute. 1991; 83:1164-1168.

44. Rowinsky EK, Grochow LB, Hendricks CB, Ettinger DS, Forastiere AA, Hurowitz LA, McGuire WP, Sartorius SE, Lubejko BG, Kaufmann SH and et al. Phase I and pharmacologic study of topotecan: a novel topoisomerase I inhibitor. Journal of clinical oncology. 1992; 10:647-656.

45. Keshelava N, Groshen S and Reynolds CP. Cross-resistance of topoisomerase I and II inhibitors in neuroblastoma cell lines. Cancer chemotherapy and pharmacology. 2000; 45:18.

46. Chen Y, Takita J, Choi YL, Kato M, Ohira M, Sanada M, Wang L, Soda M, Kikuchi A, Igarashi T, Nakagawara A, Hayashi Y, Mano H and Ogawa S. Oncogenic mutations of ALK kinase in neuroblastoma. Nature. 2008; 455:971-974.

47. Janoueix-Lerosey I, Lequin D, Brugieres L, Ribeiro A, de Pontual L, Combaret V, Raynal V, Puisieux A, Schleiermacher G, Pierron G, Valteau-Couanet D, Frebourg T, Michon J, Lyonnet S, Amiel J and Delattre O. Somatic and germline activating mutations of the ALK kinase receptor in neuroblastoma. Nature. 2008; 455:967-970.

48. Mosse YP, Laudenslager M, Longo L, Cole KA, Wood A, Attiyeh EF, Laquaglia MJ, Sennett R, Lynch JE, Perri P, Laureys G, Speleman F, Kim C, Hou C, Hakonarson $\mathrm{H}$, Torkamani A, et al. Identification of ALK as a major familial neuroblastoma predisposition gene. Nature. 2008; 455:930-935.

49. Heukamp LC, Thor T, Schramm A, De Preter K, Kumps C, De Wilde B, Odersky A, Peifer M, Lindner S, Spruessel A, Pattyn F, Mestdagh P, Menten B, Kuhfittig-Kulle S, Kunkele A, Konig K, et al. Targeted expression of mutated ALK induces neuroblastoma in transgenic mice. Science translational medicine. 2012; 4:141ra191.

50. Duijkers FA, Gaal J, Meijerink JP, Admiraal P, Pieters R, de Krijger RR and van Noesel MM. Anaplastic lymphoma kinase (ALK) inhibitor response in neuroblastoma is highly correlated with ALK mutation status, ALK mRNA and protein levels. Cell Oncol (Dordr). 2011; 34:409-417.

51. Bai RY, Ouyang T, Miething C, Morris SW, Peschel C and 
Duyster J. Nucleophosmin-anaplastic lymphoma kinase associated with anaplastic large-cell lymphoma activates the phosphatidylinositol 3-kinase/Akt antiapoptotic signaling pathway. Blood. 2000; 96:4319-4327.

52. Dan HC, Sun M, Kaneko S, Feldman RI, Nicosia SV, Wang HG, Tsang BK and Cheng JQ. Akt phosphorylation and stabilization of X-linked inhibitor of apoptosis protein (XIAP). JBiolChem. 2004; 279:5405-5412.

53. Moon JH, Shin JS, Hong SW, Jung SA, Hwang IY, Kim JH, Choi EK, Ha SH, Kim JS, Kim KM, Hong DW, Kim D, Kim YS, Kim JE, Kim KP, Hong YS, et al. A novel smallmolecule IAP antagonist, AZD5582, draws Mcl-1 downregulation for induction of apoptosis through targeting of cIAP1 and XIAP in human pancreatic cancer. Oncotarget. 2015; 6:26895-26908. doi: 10.18632/oncotarget.4822.

54. Siebert N, Seidel D, Eger C, Juttner M and Lode HN. Functional bioassays for immune monitoring of high-risk neuroblastoma patients treated with ch14.18/CHO anti-GD2 antibody. PloS one. 2014; 9:e107692.

55. Lutz W, Stohr M, Schurmann J, Wenzel A, Lohr A and Schwab M. Conditional expression of N-myc in human neuroblastoma cells increases expression of alphaprothymosin and ornithine decarboxylase and accelerates progression into S-phase early after mitogenic stimulation of quiescent cells. Oncogene. 1996; 13:803-812.

56. Dickson PV, Hamner B, Ng CY, Hall MM, Zhou J, Hargrove PW, McCarville MB and Davidoff AM. In vivo bioluminescence imaging for early detection and monitoring of disease progression in a murine model of neuroblastoma. Journal of pediatric surgery. 2007; 42:1172-1179.

57. Chou TC. Theoretical basis, experimental design, and computerized simulation of synergism and antagonism in drug combination studies. PharmacolRev. 2006; 58:621681.

58. Schwab M, Alitalo K, Klempnauer KH, Varmus HE, Bishop JM, Gilbert F, Brodeur G, Goldstein M and Trent J. Amplified DNA with limited homology to myc cellular oncogene is shared by human neuroblastoma cell lines and a neuroblastoma tumour. Nature. 1983; 305:245-248.

59. Woessmann W, Chen X and Borkhardt A. Ras-mediated activation of ERK by cisplatin induces cell death independently of p53 in osteosarcoma and neuroblastoma cell lines. Cancer chemotherapy and pharmacology. 2002; 50:397-404.
60. Cheng M, Quail MR, Gingrich DE, Ott GR, Lu L, Wan W, Albom MS, Angeles TS, Aimone LD, Cristofani F, Machiorlatti R, Abele C, Ator MA, Dorsey BD, Inghirami $\mathrm{G}$ and Ruggeri BA. CEP-28122, a highly potent and selective orally active inhibitor of anaplastic lymphoma kinase with antitumor activity in experimental models of human cancers. Molecular cancer therapeutics. 2012; 11:670-679.

61. Carr J, Bell E, Pearson AD, Kees UR, Beris H, Lunec J and Tweddle DA. Increased frequency of aberrations in the p53/MDM2/p14(ARF) pathway in neuroblastoma cell lines established at relapse. Cancer research. 2006; 66:21382145 .

62. Gilbert F, Feder M, Balaban G, Brangman D, Lurie DK, Podolsky R, Rinaldt V, Vinikoor N and Weisband J. Human neuroblastomas and abnormalities of chromosomes 1 and 17. Cancer research. 1984; 44:5444-5449.

63. White PS, Maris JM, Beltinger C, Sulman E, Marshall HN, Fujimori M, Kaufman BA, Biegel JA, Allen C, Hilliard C, Valentine MB, Look AT, Enomoto H, Sakiyama S and Brodeur GM. A region of consistent deletion in neuroblastoma maps within human chromosome 1p36.236.3. Proceedings of the National Academy of Sciences of the United States of America. 1995; 92:5520-5524.

64. Goldschneider D, Horvilleur E, Plassa LF, GuillaudBataille M, Million K, Wittmer-Dupret E, Danglot G, de The H, Benard J, May E and Douc-Rasy S. Expression of C-terminal deleted p53 isoforms in neuroblastoma. Nucleic acids research. 2006; 34:5603-5612.

65. Tweddle DA, Malcolm AJ, Bown N, Pearson AD and Lunec J. Evidence for the development of p53 mutations after cytotoxic therapy in a neuroblastoma cell line. Cancer research. 2001; 61:8-13.

66. Kaghad M, Bonnet H, Yang A, Creancier L, Biscan JC, Valent A, Minty A, Chalon P, Lelias JM, Dumont X, Ferrara P, McKeon F and Caput D. Monoallelically expressed gene related to $\mathrm{p} 53$ at $1 \mathrm{p} 36$, a region frequently deleted in neuroblastoma and other human cancers. Cell. 1997; 90:809-819.

67. Karlsson J, Ora I, Porn-Ares I and Pahlman S. Arsenic trioxide-induced death of neuroblastoma cells involves activation of Bax and does not require $\mathrm{p} 53$. Clinical cancer research. 2004; 10:3179-3188. 